REVIEW ARTICLE

\title{
Some aspects of the taxonomy and biology of adult spirurine nematodes parasitic in fishes: a review
}

\author{
František Moravec
}

Institute of Parasitology, Biology Centre, Academy of Sciences of the Czech Republic, Branišovská 31, 37005 České

Budějovice, Czech Republic

Key words: Nematoda, Spirurina, Cystidicolidae, Rhabdochonidae, parasites, fish, taxonomy, biology

\begin{abstract}
About 300 species belonging to four superfamilies (Gnathostomatoidea, Habronematoidea, Physalopteroidea and Thelazioidea) of the nematode suborder Spirurina are known as the adult parasites of freshwater, brackish-water and marine fishes. They are placed in four families, of which the Gnathostomatidae, including Echinocephalus with a few species and the monotypic Metaleptus, are parasites of elasmobranchs, whereas Ancyracanthus contains one species in teleosts; the Physalopteridae is represented in fish by four genera, Bulbocephalus, Heliconema, Paraleptus and Proleptus, each with several species in both elasmobranchs and teleosts. The majority of fish spirurines belongs to the Rhabdochonidae, which includes 10 genera (Beaninema, Fellicola, Hepatinema, Heptochona, Johnstonmawsonia, Megachona, Pancreatonema, Prosungulonema, Rhabdochona and Vasorhabdochona) of species parasitizing mainly teleosts, rarely elasmobranchs, and the Cystidicolidae with about 23 genera (Ascarophis, Caballeronema, Capillospirura, Comephoronema, Crenatobronema, Cristitectus, Ctenascarophis, Cyclozone, Cystidicola, Cystidicoloides, Johnstonmawsonoides, Metabronema, Moravecnema, Neoascarophis, Parascarophis, Prospinitectus, Pseudascarophis, Pseudoproleptus, Salvelinema, Similascarophis, Spinitectoides, Spinitectus, Sterliadochona), with many species parasitic in teleosts only. Because of difficulties in studying fish spirurines, associated with their morphological and biological peculiarities, most species of these parasites are poorly known. It is apparent that their present classification system does not reflect phylogenetic relationships and a taxonomic revision of this nematode group, based on detailed morphological (including SEM and TEM), life history and molecular studies of individual species, is quite necessary. In Cystidicolidae, several genera have been based on details in the cephalic structures visible only with the aid of SEM, but it will be evident whether or not these tiny features are of generic importance only when more cystidicolids are described using SEM and comparative molecular data become available. Data on the biology of fish spirurines are scarce. In known cases, their life cycles involve aquatic arthropods (crustaceans or insects) as intermediate hosts, in which, sometimes, the larvae undergo a precocious development and may even attain adulthood and become gravid in these invertebrates; sometimes, fish paratenic hosts are known to occur in cystidicolids parasitizing as adults piscivorous definitive hosts. Some spirurine species are pathogenic and are known as causative agents of serious fish diseases. Consequently, further detailed studies on fish spirurines are significant not only from the theoretical viewpoint, but they may also have practical implications.
\end{abstract}

According to the recently proposed system for Nematoda by De Ley and Blaxter $(2002,2004)$ largely based on molecular trees, the suborder Spirurina is very large, including 21 superfamilies, 9 of which have species that have adults in fishes. However, taking into account recent papers of Wijová et al. (2006) and mainly of Nadler et al. (2007), such a classification system seems to be too premature and much will have to be done to develop a new acceptable system for zooparasitic nematodes. Therefore, the suborder Spirurina in the conception of Chabaud (1974), based on morphological and biological data, is used in this paper.

Spirurine nematodes, which are characterized by certain morphological features and some biological peculiarities, represent a large, diverse group of parasites with a worldwide distribution. Their larvae are usually with cephalic hooks or spines and their oesophageal glands are multinucleate. Adults are parasites of the digestive tract or tissues of hosts belonging to all classes of verte- brates and their intermediate hosts are invertebrates other than copepods (except Gnathostomatoidea) (Chabaud 1974).

Members from fishes are noted for a high degree of variability in the structure of the cephalic end (Figs. 14). Their mouth is usually bilaterally symmetrical, with more or less developed lateral lips (pseudolabia), which may be completely absent in some groups; the mouth aperture may be circular, hexagonal, dorsoventrally elongate-oval or slit-like, frequently provided with various sclerotized formations as plates, teeth or spines. Cephalic papillae are variable in number, usually arranged in two circles; mostly four larger submedian papillae are present. The cuticle is usually finely transversely striated, sometimes ornamented with transverse rows of spines or other formations. Mostly a welldeveloped, sclerotized stoma (vestibule) is present. The oesophagus is usually distinctly separated into an anterior muscular portion and a longer posterior glandular 
portion (Fig. 2 A); this separation may be indistinct in some groups. Two spicules are present. The male posterior end is frequently provided with caudal alae and usually many preanal and postanal genital papillae are present (Fig. 5). All species are oviparous and fully developed eggs of some species are provided with polar filaments or with special polar or equatorial swellings (Fig. 6). The mature eggs of most spirurine species already contain fully formed first-stage larvae, which do not hatch spontaneously in the external environment (Fig. 2 D, I). In contrast, the eggs of species belonging to the Gnathostomatoidea are uncleaved at the time of oviposition (Fig. $1 \mathrm{C}, \mathrm{G}, \mathrm{K}$ ), and the larvae develop in them only in the external environment; the larvae undergo their first moult inside the egg shells and hatch in the external environment. Sexual dimorphism is not too marked in spirurines. The body size of gravid females in fish spirurines is usually from about 1 to several $\mathrm{cm}$.

The Spirurina comprises ten superfamilies, of which only four, the Gnathostomatoidea Railliet, 1895, Habronematoidea Chitwood et Wehr, 1932, Physalopteroidea Railliet, 1893 and Thelazioidea Skryabin, 1915, contain species (about 300) parasitic as adults in freshwater, brackish-water or marine fishes, whereas members of remaining six spirurine superfamilies are parasites exclusively of amphibians, reptiles, birds and mammals including humans (Chabaud 1975a, b). Each of the above mentioned spirurine superfamilies with fish parasites comprises a single family in which these fish nematodes are placed: Gnathostomatidae Railliet, 1895 (3 genera, 12 species) in Gnathostomatoidea; Physalopteridae Railliet, 1893 (4 genera, about 37 species) in Physalopteroidea; Cystidicolidae Skryabin, 1946 (23 genera, about 140 species) in Habronematoidea; and Rhabdochonidae Travassos, Artigas et Pereira, 1928 (10 genera, about 114 species) in Thelazioidea.

Sometimes, representatives of Hedruris Nitzsch, 1812 belonging to another habronematoid family Hedruridae Railliet, 1916 are reported from fishes. However, species of this genus are parasites of amphibians and turtles (Chabaud and Bain 1994), exhibiting a precocious development in the invertebrate intermediate host (Petter 1971), so that fish may acquire these nematodes by accidental swallowing up their true amphibian hosts or invertebrate hosts harbouring adult worms (Moravec 1994). Therefore, fishes cannot be considered their true definitive hosts, but only facultative postcyclic hosts as defined by Odening (1976).

The present author does not consider it useful to provide a key to the families and genera of fish Spirurina or to list valid spirurine species in this paper, because important taxonomic changes are expected soon, as indicated by contemporary studies (see Moravec 2007a). The fish spirurines will be dealt with in detail in the author's revisional papers intended to be published within a few next years.
Some species of adult fish spirurines parasitize a wide range of hosts; others exhibit a relatively narrow host specificity. Within the Gnathostomatidae, the genus Echinocephalus Molin, 1858 with a few widely distributed species and the monotypic Metaleptus Machida, Ogawa et Okiyama, 1982 include parasites of elasmobranchs (rays and sharks) (Machida et al. 1982, Moravec and Nagasawa 2000), whereas the only species of Ancyracanthus Diesing, 1838 from fish is known to parasitize Neotropical freshwater teleosts (characids) (Gomes and Kohn 1970, Moravec 1998). All these species are gastrointestinal parasites. The record of a representative of another gnathostomatid genus Gnathostoma Owen, 1836, G. gracile (Diesing, 1839), from the intestine of the Neotropical osteoglossiform fish Arapaima gigas (Schinz) (Diesing 1839) was evidently accidental, and the fish probably acquired the nematodes after swallowing their true mammalian definitive host (Moravec 1998).

All representatives of the Physalopteridae from fishes belong to the subfamily Proleptinae Railliet, 1893. Members of different genera of these marine gastrointestinal parasites occur in distinct hosts. Whereas species of Proleptus Dujardin, 1845 and Paraleptus Wu, 1927 are parasites mainly of elasmobranchs, those of Heliconema Travassos, 1919 are parasitic in teleosts, particularly anguilliforms. Species of Bulbocephalus Rasheed, 1966 occur in teleosts in Asia (Chabaud and Bain 1994, Moravec et al. 2007a).

Hosts of the numerous species of the Cystidicolidae are exclusively marine and freshwater fishes, largely teleosts (Chabaud and Bain 1994). Cystidicolids are mostly gastrointestinal parasites; only representatives of the genera Cystidicola Fischer, 1798, Metabronema Yorke et Maplestone, 1926 and Salvelinema Trofimenko, 1962 are parasites of the swimbladder. They have cosmopolitan distribution and some species (e.g., some members of Ascarophis van Beneden, 1871, Moravecnema Justine, Cassone et Petter, 2002, Neoascarophis Machida, 1976 or Spinitectus Fourment, 1884) are even known to parasitize deep-sea fishes (Klimpel et al. 2001, Justine et al. 2002, Moravec and Klimpel 2007a).

With the exception of a few species of Trichospirura Smith et Chitwood, 1967 parasitizing amphibians, reptiles and mammals in the tropics, all the other numerous species of the Rhabdochonidae are the parasites of fishes. The majority of them are representatives of Rhabdochona Railliet, 1916, intestinal parasites of exclusively freshwater teleosts occurring in all zoogeographical regions except for the Australian one (Moravec 1975, Chabaud and Bain 1994); the restriction of their occurrence to a freshwater environment is evidently associated with the fact that their obligate intermediate hosts are aquatic insects (Moravec 1994). Additional two genera represented by a few freshwater species are Prosungulonema Roitman, 1963 and Beaninema 
A

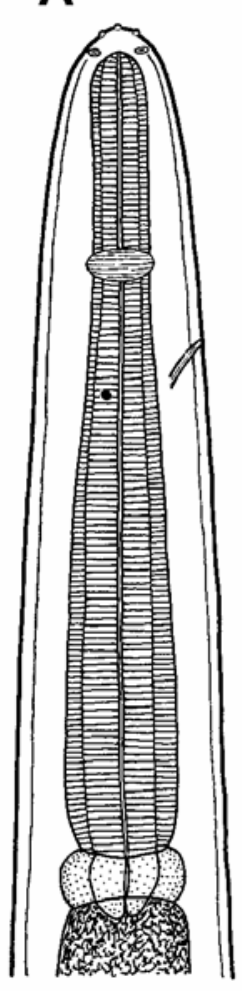

D

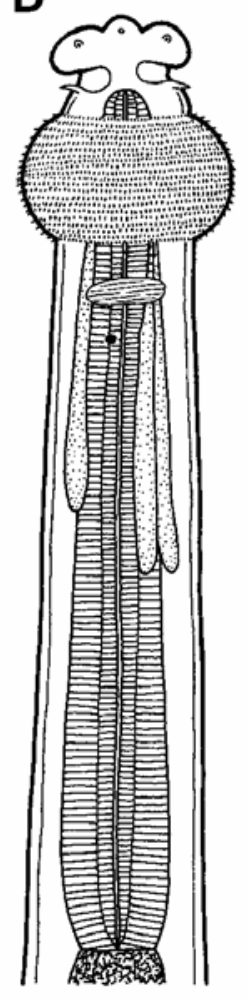

$\mathbf{H}$

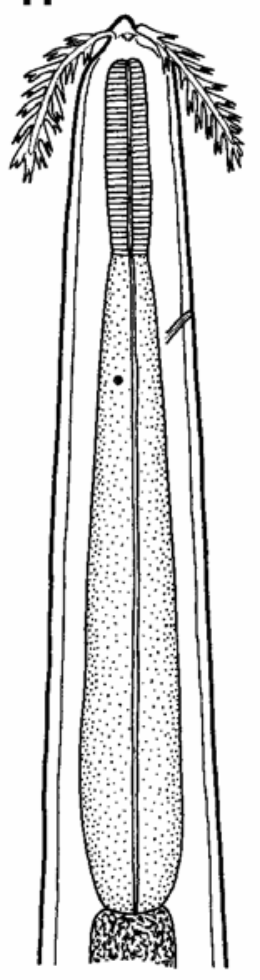

B
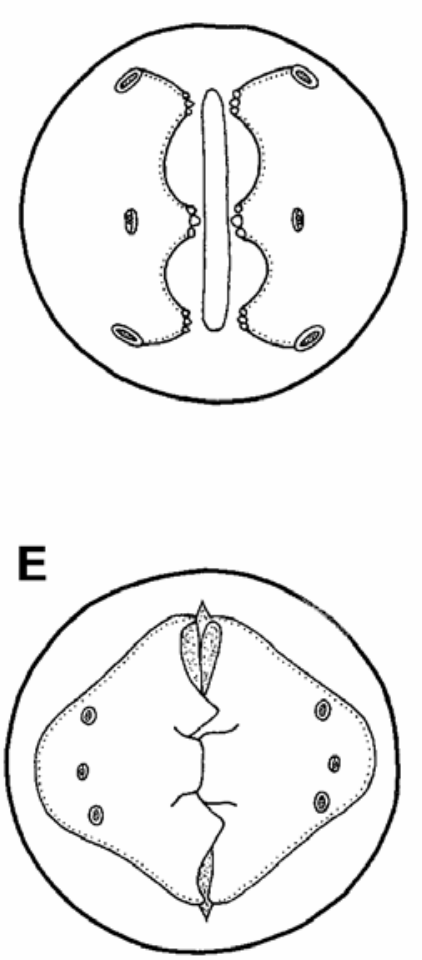
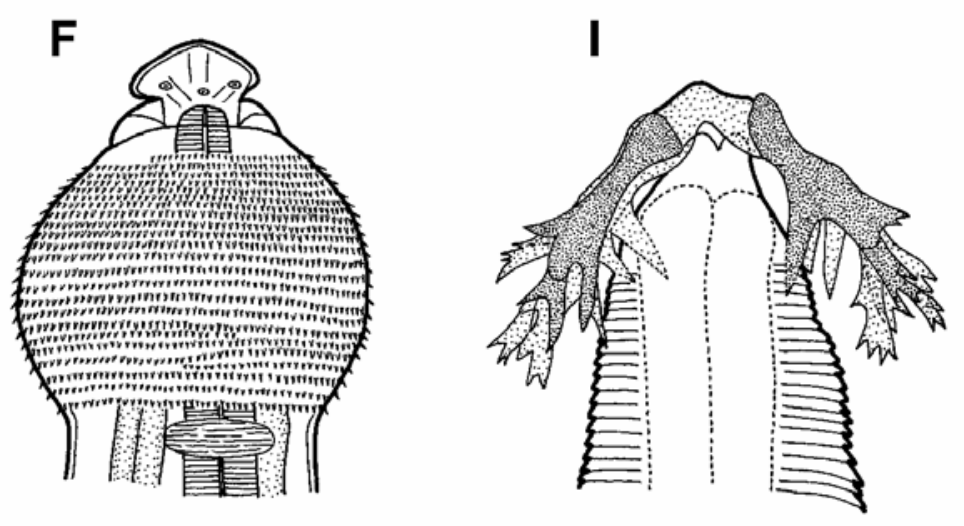

$\mathbf{J}$
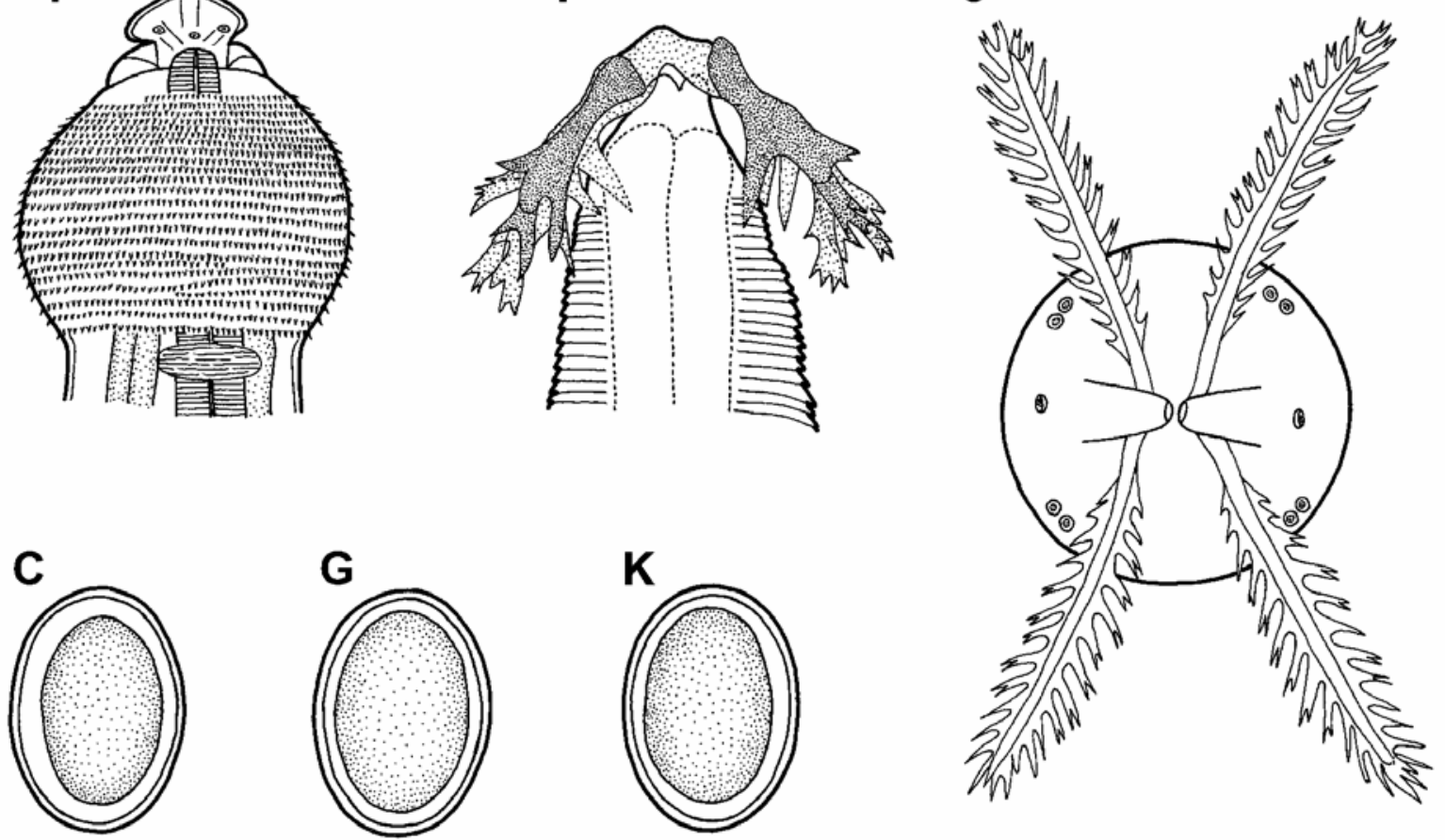

Fig. 1. Main types of Gnathostomatoidea from fishes. A-C - Metaleptus (A - anterior end; B - cephalic end, apical view; C - mature egg); D-G - Echinocephalus (D - anterior end; E, F - cephalic end, apical and lateral views; G - mature egg); $\mathbf{H}-\mathbf{K}$ - Ancyracanthus (H - anterior end; I, J - cephalic end, lateral and apical views; $\mathrm{K}$ - mature egg). 
Caspeta-Mandujano, Moravec et Salgado-Maldonado, 2001, parasites of the intestine and the gall-bladder, respectively, of teleosts. An additional seven rhabdochonid genera comprise each a few species adapted to marine and brackish-water fishes or to extraintestinal locations: liver, pancreas, gall-bladder, blood stream, body cavity; they are mostly the parasites of teleosts, rarely of elasmobranchs (only Pancreatonema McVicar et Gibson, 1975).

The life cycles of fish spirurines involve aquatic arthropods (crustaceans or aquatic insects) as obligate intermediate hosts; thus they resemble those of other spirurid nematodes parasitizing terrestrial vertebrates where a variety of arthropods serve as intermediate hosts (Anderson 2000). Although the development of these fish nematodes in the invertebrate intermediate host is usually completed by attaining the third-stage larva, which is already infective for the definitive host, in some species it can continue further (a precocious development) and even the adult stage can be attained in such an invertebrate (Moravec 1994). Paratenic and postcyclic parasitism also frequently occur in fish spirurines (Moravec 1994).

Fish spirurine nematodes are widely distributed among freshwater, brackish-water and marine fishes, being reported from at least 400 fish species, belonging to 105 fish families and 30 orders. Sometimes these nematodes occur in large numbers in their piscine hosts, which suggests that they may affect the health condition of the fish and decrease its resistance against secondary infections. Some of these nematodes were recorded as important pathogens of fishes, for example, Cystidicola farionis Fischer, 1798, a swimbladder parasite of salmonids or Spinitectus inermis (Zeder, 1800) and $S$. carolini Holl, 1928, parasites of the digestive tract of European eels and North American fishes, respectively (Schäperclaus 1954, Kinkelin et al. 1973, Bauer et al. 1977, Jilek and Crites 1982a).

Some fish spirurines (Rhabdochona, Salvelinema) are transmitted in fresh waters only, from where, during migrations of their hosts, they may be brought into the brackish or sea waters. In such cases, it is possible to utilize them as so called "biological tags" for determination from where the stocks of migrating fishes originated (Margolis 1963, Moravec 1975).

In addition to adult forms, fishes may harbour larval spirurines, serving thus as paratenic hosts for many species parasitic in adulthood in terrestrial vertebrates, mainly birds and mammals but also fishes and an additional source of infection for the definitive host (Moravec 1994, Anderson 2000).

Besides the practical importance of fish spirurines as pathogens, this nematode group represents a significant experimental group for testing theoretical questions concerning the host-parasite relationships, morphological adaptations to parasitism, biology, ecology, zoogeography and phylogeny of these parasites and their fish hosts, as also some questions of general biology. For example, the distribution of individual freshwater $R h a b$ dochona spp. is often limited and, therefore, this group may be useful for studies of the zoogeographical affinities among different faunae as well as for support of theories regarding the migrations and phylogenies of the hosts. However, the exact specific identification of the parasites is a prerequisite for such an attempt (Moravec 1975).

In view of problems to study in detail their morphology by light microscopy, often inadequate or erroneous descriptions of many species, and because of some biological peculiarities of these nematodes such as a precocious development in the intermediate host or a high degree of intraspecific morphological variability, the majority of fish spirurines remains poorly known and the classification within this parasite group is usually difficult and unsatisfactory.

\section{TAXONOMY AND CLASSIFICATION}

The first presently valid fish spirurine species was described by Fischer (1798) as Cystidicola farionis from the swimbladder of the brown trout Salmo trutta fario L. in Europe. During the 19th century, a few additional fish spirurines were discovered and described in Europe, for example Proleptus acutus Dujardin, 1845 and $P$. obtusus Dujardin, 1845, Rhabdochona denudata (Dujardin, 1845), Echinocephalus uncinatus Molin, 1848, Ascarophis morrhuae van Beneden, 1871 or Spinitectus oviflagellis Fourment, 1884, and in North America (Cystidicola serrata (Wright, 1879) [species inquirenda] and Filaria stigmatura Leidy, 1886 [= syn. of Sterliadochona ephemeridarum (Linstow, 1872)]). However, already earlier, two common European fish spirurines, Sterliadochona ephemeridarum and Rhabdochona hellichi (Šrámek, 1901), were apparently reported under the names Fusaria (or Spiroptera) tenuissima Zeder, 1800 and Fusaria (or Ascaris) dentata Zeder, 1800, both now considered species inquirendae (Moravec 1975, 1981). During the 20th century, the number of nominal species of fish spirurines considerably increased, but their identification often became problematic mainly because of many inadequate species descriptions and problems with the delimitation of genera.

In the past, fish spirurines were assigned by authors to different genera such as, for example, Fusaria Zeder, 1800, Spiroptera Rudolphi, 1819, Dispharagus Dujardin, 1845, Histiocephalus Diesing, 1851, Ichthyospirura Skryabin, 1917, Pseudancyracanthus Skryabin, 1923 or Pseudocystidicola Layman, 1933, which are no longer valid for these parasites. However, in addition to already existing Cystidicola Fischer, 1798, Proleptus Dujardin, 1845, Echinocephalus Molin, 1858, Ascarophis van Beneden, 1871 and Spinitectus Fourment, 1884, some other new genera were established: Capillospirura Skryabin, 1924, Metabronema Yorke et Maplestone, 1926, Cyclozone Dogiel, 1932, Comephoronema Lay- 
A

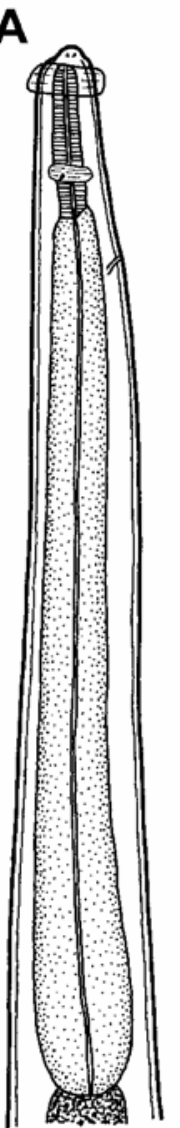

B
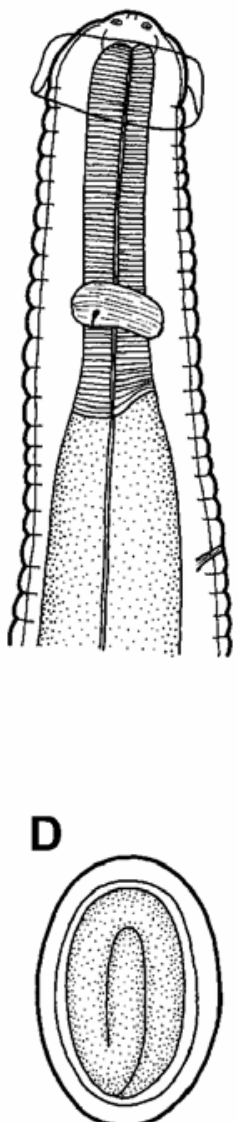

C

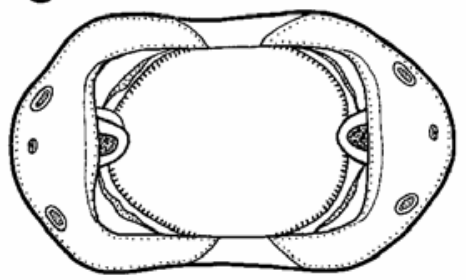

$\mathbf{E}$

G

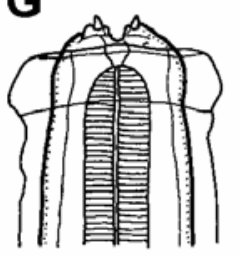

I
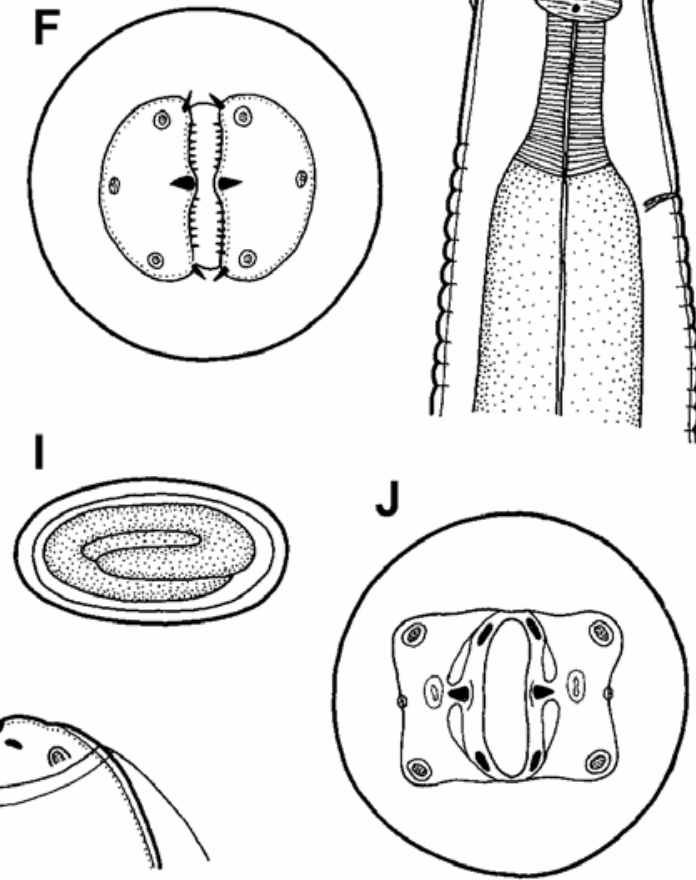

Fig. 2. Main types of Physalopteroidea (Proleptinae) from fishes. A-D - Proleptus (A - anterior part of body; B - cephalic end, lateral view; C - mouth, apical view; D - mature egg); E-G - Paraleptus (E, F - cephalic end, lateral and apical views; G anterior end of body, dorsoventral view); H-K - Heliconema $(\mathrm{H}$ - anterior end; I - mature egg; J, K - cephalic end, apical and dorsoventral views).

man, 1933, Cystidicoloides Skinker, 1931, Sterliadochona Skryabin, 1948, Johnstonmawsonia CampanaRouget, 1955, Parascarophis Campana-Rouget, 1955 and Pseudoproleptus Khera, 1955.

Rasheed (1966), who attempted to revise the fish "spiruroid" nematodes known at that time, could state: "A review of the literature reveals that the majority of the spiruroid parasites is not well defined and they are so closely allied to each other that in some cases the distinction is not more than specific. The allocation of these genera to the various families and subfamilies also varies from one author to the other. Thus, when pursuing the morphological relationships in the systematics and taxonomy of the spiruroids of fish, one is faced with so many complexities that it is impossible to come to a satisfactory conclusion. This confusion mainly arose from the continual addition of species, genera, and subfamilies to the already existing ones. The descriptions and diagnosis of most of these are not satisfactory."
Very important for those who study fish spirurine nematodes were the Russian monographs by Skryabin and Sobolev (1964), Skryabin et al. (1967a, b) and Ivashkin and Khromova (1976), compiled from the extensive world literature and providing descriptions and illustrations of all then-known species. In accordance with their classification system, the Gnathostomatoidea was assigned to a separate suborder Gnathostomatata Skryabin et Ivashkin, 1973, the Physalopteroidea to the suborder Spirurata Railliet, 1914, and all other genera of fish spirurines to the superfamily Thelazioidea sensu Sobolev, 1949, Spirurata. However, the most satisfactory classification system of these parasites seemed to be that given by Chabaud $(1974,1975 a, b)$ in the CIH Keys to the Nematode Parasites of Vertebrates, where all these parasites were included in the order Spirurina (see above). 


\section{G n a thos to m a t id a e}

It has been mentioned above that the family Gnathostomatidae comprises only three genera with adult representatives parasitizing fishes. The genus Echinocephalus includes at present ten valid species that are limited in host distribution primarily to marine and freshwater stingrays (Hoberg et al. 1998). Several species of this genus were described in detail during recent decades; SEM proved to be a very useful method especially for the study of the structure of pseudolabia, spines on the cephalic bulb, genital papillae and precloacal ventral cuticular ornamentations in the male (e.g., Deardorff and Ko 1983, Beveridge 1985, 1987, Hoberg et al. 1998, Moravec and Justine 2006). Hoberg et al (1998) also provided a phylogenetic analysis of Echinocephalus spp. based on morphological features. Larvae of Echinocephalus are frequently found in a variety of teleosts and molluscs, serving apparently as paratenic hosts, but their species identification is problematic. Moravec and Justine (2006) pointed out that the numbers and arrangement of minute spines in the anterior dorsal and ventral groups on the cephalic bulb may be a rather reliable taxonomic criterion for their identification, but these have to be studied using SEM.

A new remarkable nematode representing a new species of a new genus, Metaleptus rabuka, was described by Machida et al. (1982) from the gastrointestinal tract of the deep-sea frilled shark Chlamydoselachus anguineus Garman off Japan. Although it evidently belongs to Spirurina, its morphology differs from other species of this group mainly in possessing a ventriculuslike formation between the oesophagus and the intestine (called the oesophagointestinal valve by Machida et al. 1982), resembling the ventriculus in anisakid nematodes. The authors assigned this species to the family Physalopteridae. The same species was later redescribed from newly collected specimens from the deep-sea shark Apristurus fedorovi Dolganov in Japan by Moravec and Nagasawa (2000); based on a SEM study of the cephalic end, they transferred it from the Physalopteridae to the Gnathostomatidae, where they established a new subfamily Metaleptinae to accommodate it. Apparently, this is an archaic form indicating affinities of spirurine nematodes to ascaridoids. The third gnathostomatid genus containing adult species parasitizing fishes is Ancyracanthus, characterized by the cephalic end provided with two pairs of conspicuous ramified appendages oriented posteriorly; only one species, $A$. schubarti (Kohn, Gomes et Motta, 1968) is parasitic in Neotropical characids (Gomes and Kohn 1970, Moravec 1998), whereas the other congener is a parasite of chelonians.

\section{Phy s a lopt e rida e}

Within the Proleptinae of the family Physalopteridae, Chabaud (1975a) recognized four genera, Bulbocephalus, Heliconema, Paraleptus and Proleptus (see above), whereas the morphologically similar Cyclozone Dogiel,
1932 and Pseudoleptus Khera, 1955, originally assigned to the Physalopteridae, were listed in the habronematoid family Cystidicolidae. In the same year, Specian et al. (1975) erected a new genus Neoleptus, revised species of Proleptus, and provided a key to the genera of Proleptinae. Unfortunately, in these keys given by both Chabaud (1975a) and Specian et al. (1975), differential features, such as the position of the vulva, the length ratio of the spicules or the character of genital papillae, are used, which, in our opinion, are only of specific significance (Moravec et al. 2007a). For example, in different species of cystidicolids (e.g., Spinitectus) the situation of the vulva is highly variable and the same concerns the length ratio of spicules in cystidicolids or rhabdochonids (e.g., Ascarophis, Rhabdochona, Spinitectus). Therefore, the establishment of Neoleptus Specian, Ubelaker et Dailey, 1975 does not seem to be substantiated and, consequently, this name should be considered a junior synonym of Paraleptus. Specian et al. (1975) also reported Dogielina Sobolev, 1949 as a valid genus belonging to Proleptinae, but, because of its poor knowledge, it was not classified by Chabaud (1975a), whereas Skryabina (1974) regarded it a possible synonym of Cyclozone.

As already mentioned by Specian et al. (1975) for Proleptus spp., the taxonomy of species of the Proleptinae is confusing, because many species are based on a few specimens and usually lack adequate figures and measurements. The situation is further complicated by a considerable intraspecific biometrical variability of these nematodes and inaccurate observations on their morphology by different authors, which probably results in frequent generic or species misidentifications.

Moravec et al. (2007a) have recently indicated that the delimitation of genera within the Proleptinae, which are objectively determined by their type species, should be based on the cephalic structures. It has already been suggested by Chitwood and Wehr (1934) that the morphological structure of the cephalic region should be used as an important character in the classification of spiruroid nematodes. In physalopterids, Chabaud (1975a) regarded the cephalic dentation, which corresponds to a great extent with a distribution in one or another group of hosts, to be a valuable character.

Of the four valid genera of the Proleptinae, Bulbocephalus is easily distinguished by the unusual structure of its cephalic end (presence of protrusible oesophageal lobes, reduced pseudolabia, absence of cephalic collarette). However, the characters of the remaining three genera are rather similar and in fact, there are frequent confusions in assigning different species to these genera. It is clear that there is a need to re-diagnose them on the basis of a detailed study of the cephalic structures of their type species, all of which are inadequately described in this respect. Until a relevant revision is made, Moravec et al. (2007a) suggest distinguishing these three genera on the basis of their cephalic dentation: 

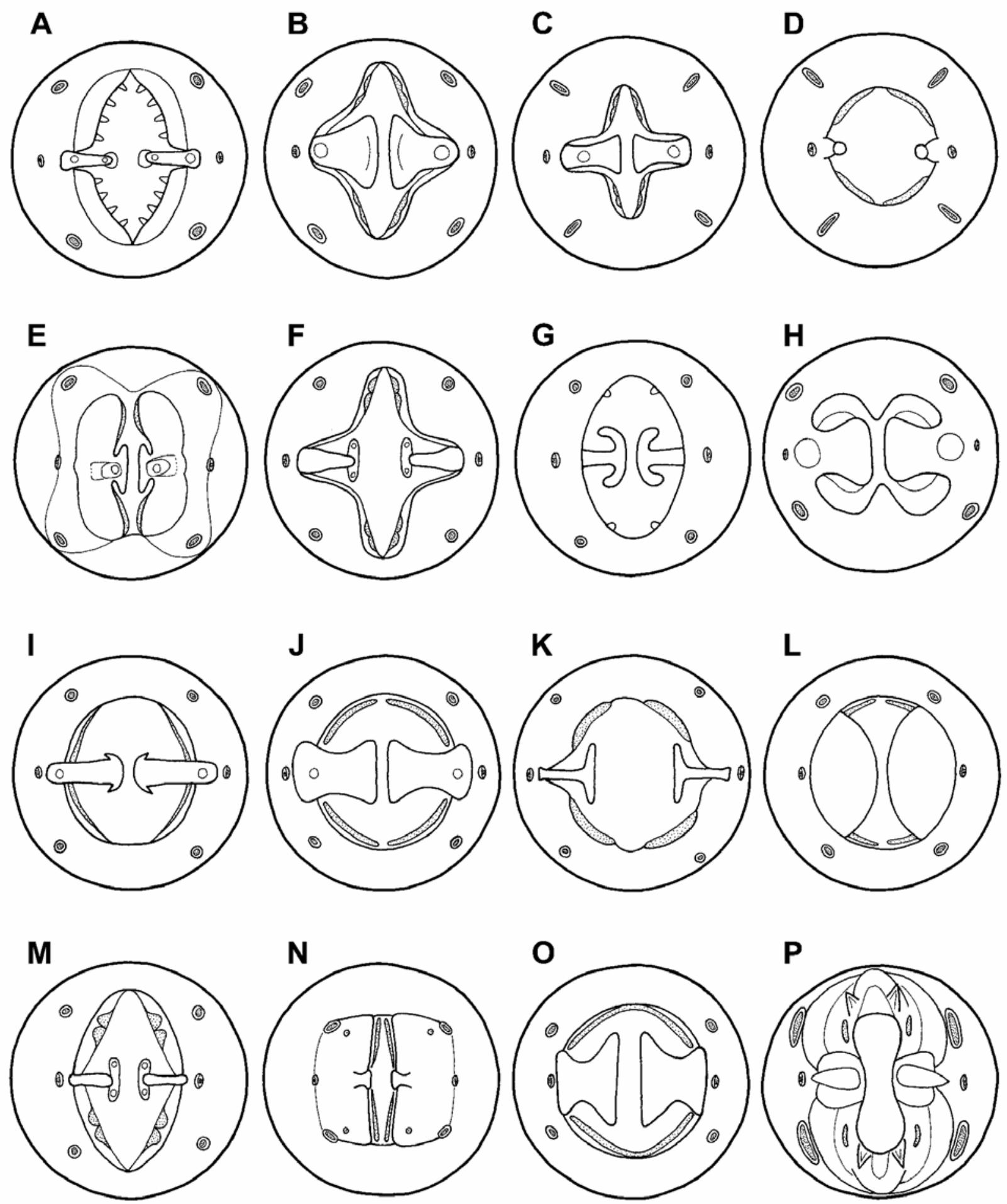

Fig. 3. Variations in the structure of mouth in some cystidicolid nematodes (apical views, schematized). A - Cystidicola; $\mathbf{B}$ - Comephoronema; C - Ascarophis (Ascarophis); D - Ascarophis (Similascarophis); E - Neoascarophis; $\mathbf{F}$ - Capillospirura; $\mathbf{G}$ - Pseudascarophis; H-Metabronema; I - Salvelinema; J - Sterliadochona $; \mathbf{K}$-Spinitectus (S. oviflagellis); L - Prospinitectus; $\mathbf{M}$ - Caballeronema $\mathbf{N}$ - Cristitectus; $\mathbf{O}$-Spinitectus (S. carolini); $\mathbf{P}$ - Cystidicoloides. 
Heliconema: Internal border of each pseudolabium with an internolateral tooth only and usually with a simple tooth at each dorsoventral extremity. Mostly parasites of teleosts, particularly anguilliforms.

Paraleptus: Internal border of each pseudolabium with a series of larger denticles in addition to the internolateral tooth. Mainly parasites of elasmobranchs.

Proleptus: Each pseudolabium with a single internolateral tooth; outer rim of buccal cavity wall with a circumoral row of minute denticles (serrations). Mainly parasites of elasmobranchs.

However, it is necessary to note that the cephalic structures of most proleptine species have not yet been studied in detail (preferably by SEM) (see Moravec et al. 2002a) and, accordingly, their present generic allocations may not be correct. Some morphological structures of these nematodes are difficult to observe under the light microscope and, therefore, some species are evidently inadequately described. Moreover, Fusco and Palmieri (1980) started to use in Heliconema spp. the numbers of ventral precloacal tessellated longitudinal ridges (area rugosa) as the principle differentiating feature between the species, which was followed by some subsequent authors. However, as Moravec et al. (2007a) remark, this feature is quite unreliable, because the number of such ridges is rather variable within a species and depends partly on the body size and age of the worm.

\section{Cyst i d i c o li d a e}

Regarding taxonomy and classification system, apparently the most complicated situation is in the family Cystidicolidae. During recent decades, the system of these nematodes underwent considerable changes, but the opinions of various authors on the systematic status of individual genera were often very different. This instability was mainly due to many taxonomic uncertainties, mostly in the evaluation of various features as generic criteria. Even though much confusion in this group has remained to date, the work of Rasheed (1966), Margolis (1967), Ko and Anderson (1969) and many others in the second half of the last century synonymized many forms and thus simplified the confused system of these nematodes. Nevertheless, many new cystidicolid genera and species are gradually being described. However, several genera have been based on details in the cephalic structures visible only with the aid of SEM and, as mentioned by Ferrer et al. (2005) and Moravec et al. (2006), it will be evident whether or not these tiny features are of generic importance only as more cystidicolids are described with the use of SEM and comparative molecular data become available.

At present, the following 23 cystidicolid genera are usually considered by different authors as possibly valid: Cystidicola Fischer, 1798, Ascarophis van Beneden, 1871, Spinitectus Fourment, 1884, Capillospirura Skryabin, 1924, Metabronema Yorke et Maplestone, 1926, Cystidicoloides Skinker, 1931, Cyclozone Dogiel,
1932, Comephoronema Layman, 1933, Sterliadochona Skryabin, 1948, Parascarophis Campana-Rouget, 1955, Pseudoproleptus Khera, 1955, Salvelinema Trofimenko, 1962, Ctenascarophis Mamaev, 1968, Spinitectoides Petter, 1969, Cristitectus Petter, 1970, Johnstonmawsonoides Machida, 1975, Neoascarophis Machida, 1976, Caballeronema Margolis, 1977, Prospinitectus Petter, 1979, Pseudascarophis Ko, Margolis et Machida, 1985, Crenatobronema Solov'eva, 1987, Moravecnema Justine, Cassone et Petter, 2002 and Similascarophis Muñoz, González et George-Nascimento, 2004.

Of them, however, Ctenatobronema and Johnstonmawsonoides are inadequately known and the validity of Prospinitectus was not accepted by Moravec et al. (2004). Muñoz et al. (2004) newly established the genus Similascarophis to accommodate Ascarophis-like nematodes with highly reduced pseudolabia, but, in view of considerable variations in the shape and size of pseudolabia in these nematodes, it was not accepted as a valid genus by Ferrer et al. (2005) and it was synonymized with Ascarophis by Moravec and González-Solís (2007); later Moravec and Justine (2007a) revalidated Similascarophis as a subgenus of Ascarophis.

The inadequately known genus Comephoronema was considered by Chabaud (1975a) to be a junior synonym of Cystidicola, but Moravec and Nagasawa (1999) revalidated this genus on the basis of Trofimenko's (1974) data on the cephalic structure of $C$. oschmarini Trofimenko, 1974, pointing out that it shows affinities more to Salvelinema than to Cystidicola. However, the SEM study of the cephalic structure of $C$. oschmarini, as well as those of Comephoronema macrochiri Moravec et Klimpel, 2007 and Cystidicola farionis (see Moravec and Rokicki 2002, Moravec et al. 2007b, Moravec and Klimpel 2007b), show that Comephoronema is in fact closest to Ascarophis (see Ko 1986), differing from it only in the more numerous pairs of preanal papillae in the male (Moravec et al. 2007b). Moravec et al. (2007b) have recently transferred to Comephoronema another species, originally listed in Rhabdochona, and provided a key to species of this genus.

Recent SEM study of the type species of Metabronema (see Moravec and Justine 2007b) and Cystidicoloides (see Moravec et al. 2008) have shown that none of these two genera can be used to accommodate the species originally described as Filaria ephemeridarum Linstow, 1872, a common and widespread parasite of salmonids, to which it was usually assigned. Therefore, for the time being, this species is assigned to the revalidated genus Sterliadochona, although the systematic status of its type species, $S$. ssavini Skryabin, 1948 , needs to be confirmed (this situation is being solved in the paper by Moravec et al. 2008).

The only spirurine species parasitizing fishes in which ultrastructure has been studied by TEM is $S$. ephemeridarum (see Frantová and Moravec 2003, 2004a, b). 

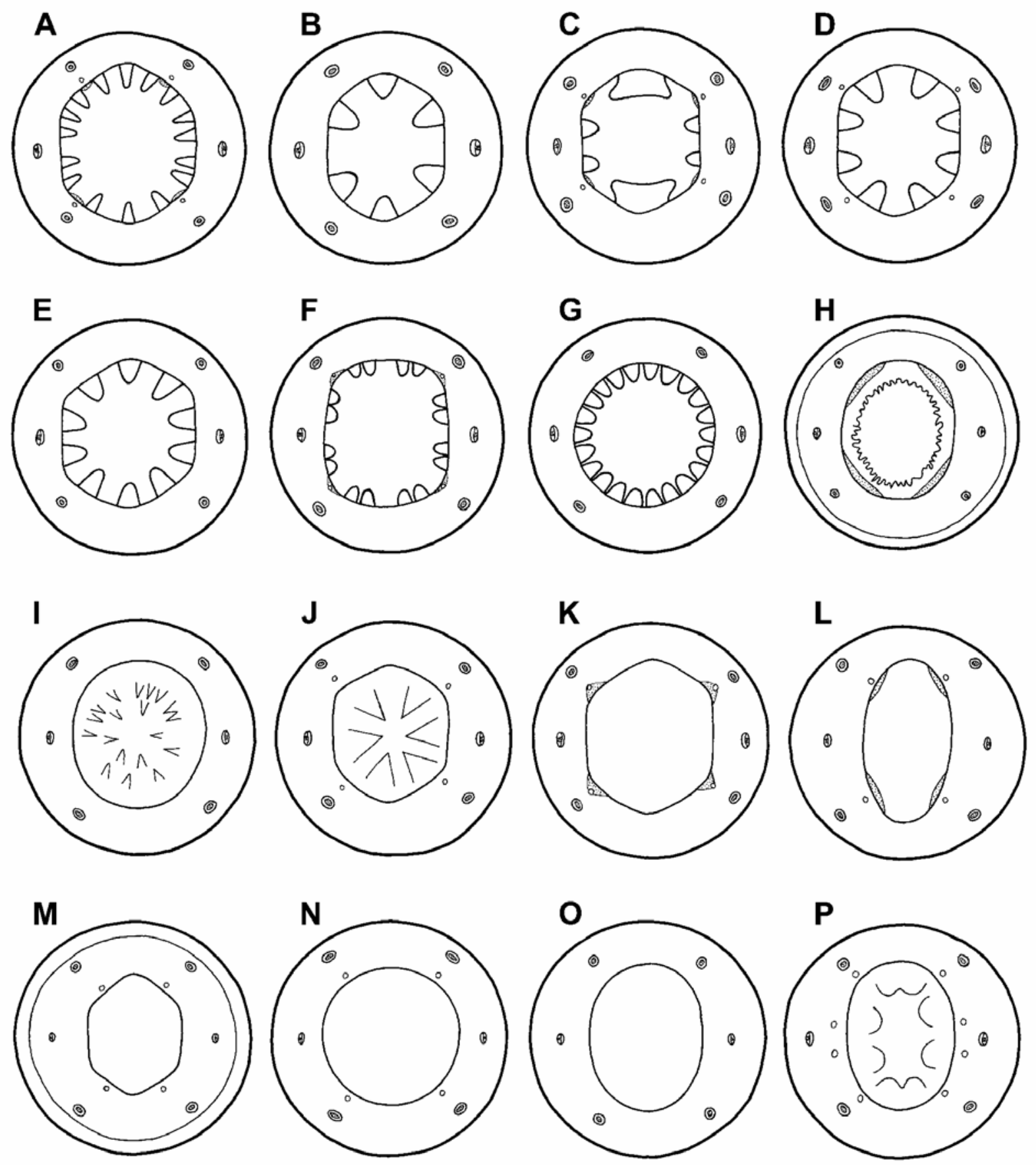

Fig. 4. Variations in the structure of mouth in rhabdochonid nematodes (apical views, schematized). A-G - Rhabdochona (A R. denudata; $\mathrm{B}-R$. longleyi; $\mathrm{C}-$ R. xiphophori; $\mathrm{D}-$ R. chodukini; $\mathrm{E}-$ R. oncorhynchi; $\mathrm{F}-$ R. guerroensis; $\mathrm{G}-$ R. euchiloglanis); $\mathbf{H}$ - Heptochona; I - Megachona; J - Beaninema; K - Prosungulonema $; \mathbf{L}$ - Pancreatonema; $\mathbf{M}$ - Hepatinema; $\mathbf{N}$ - Vasorhabdochona; $\mathbf{O}$ - Johnstonmawsonia; $\mathbf{P}$ - Fellicola. 


\section{R h a b d o c ho n i d a e}

According to Moravec et al. (2001), this family contained ten valid genera, of which the following nine included the parasites of fishes: Rhabdochona Railliet, 1916, Johnstonmawsonia Campana-Rouget, 1955, Prosungulonema Roytman, 1963, Hepatinema Rasheed, 1964, Heptochona Rasheed, 1965, Vasorhabdochona Martin et Zam, 1967, Pancreatonema McVicar et Gibson, 1975, Fellicola Petter et Køie, 1993 and Beaninema Caspeta-Mandujano, Moravec et Salgado-Maldonado, 2001; the tenth genus, Megachona Mejía-Madrid et Pérez-Ponce de León, 2007, has been erected only recently (Mejía-Madrid and Pérez-Ponce de León 2007).

Except for Rhabdochona, all these genera, each being represented by a single or just a few species, all comprise parasites of marine fishes, mostly located outside the host's digestive tube (see above); the taxonomic problems concerning these species are mainly in that only a few of them have so far been studied by SEM and the available species descriptions are frequently inadequate. The problem in representatives of some genera is also their unusual location of the nerve ring (encircling the vestibule instead of the muscular oesophagus as in most nematodes) (Fig. 5), which, moreover, is sometimes difficult to observe under the light microscope.

However, most taxonomic problems have concerned the genus Rhabdochona, comprising very numerous species parasitizing the intestine of freshwater fishes in all zoogeographical regions except for the Australian one (see above). Although in the past the taxonomy of nematodes of this genus was dealt with by many authors, in the sixties it represented one of the most perplexing groups of the nematode parasites of fishes (Rasheed 1965). Descriptions of many species were inadequate or erroneous. Frequent misidentifications of the species also resulted from considerable intraspecific variations in the morphology of these nematodes as also their possible occurrence in phylogenetically distant groups of hosts, etc. Therefore, Moravec (Moravec and Arai, 1971, Moravec 1972a, b, 1975) made a taxonomic revision of these nematodes, where, for the first time in helminths, he used the method of an extensive global revision based on a re-study of all then available materials of Rhabdochona from many scientific institutions of the world. The number of valid species was considerably reduced and the genus was subdivided into five subgenera principally based on the numbers of prostomal teeth and the structure of the female tail tip (Moravec 1975). The presence of egg filaments or swellings was taken for a good specific feature, but no greater taxonomic value was assigned to it. This system is widely used till now.

Since the revision by Moravec (1975), many new species of Rhabdochona have been described mainly from previously little-explored regions in the Americas,
Africa and Asia, so that the number of nominal species in this genus has approximately been doubled. However, even though some recently described species have also been studied by SEM, descriptions of the majority of these nematodes are again inadequate, not corresponding to the requirements of present nematode taxonomy. A remarkable recent finding is that the morphological type of Rhabdochona species characterized by a group of small cuticular processes on the female tail tip also occurs in the Neotropical Region (CaspetaMandujano and Moravec 2000); previously this morphological type was known only from Africa and South and East Asia; new data indicate certain affinities between the Neotropical and the Ethiopian faunae of these freshwater parasites.

Mejía-Madrid et al. (2007) have recently published an interesting paper reporting results of the phylogenetic analysis of 40 Rhabdochona spp., including all 21 considered valid in the Americas, based on the cladistic analysis of 51 morphological characters; the study has confirmed an ancient origin for the group. Meanwhile, however, four of the analysed North American species (R. californiensis Maggenti, Abdel-Rahman et Cid del Prado Vera, 1992, R. paxmani Maggenti, AbdelRahman et Cid del Prado Vera, 1992, R. salmonis Maggenti, Abdel-Rahman et Cid del Prado Vera, 1992, $R$. rotundicaudatum Byrne, 1992) have been suppressed by Moravec and Muzzall (2007) as junior synonyms of previously described species.

The species identification of fish spirurines, in particular those belonging to the genera comprising many species, such as Ascarophis, Spinitectus or Rhabdochona, is usually difficult, because the existing descriptions of most species are inadequate. This is frequently associated with the small body size of these nematodes and difficulties in observing their various structures under the light microscope, such as the cephalic and cuticular structures, deirids or genital papillae. Moreover, the situation may be complicated by a high degree of intraspecific variability, for instance in the number and distribution of genital papillae in Rhabdochona spp. (Moravec 1972a).

Although the mouth structures are very important for the taxonomy of spirurines, they are usually difficult to study by LM and, therefore, their examination by SEM may be quite necessary. The same concerns, for example, the cuticular ornamentations or the shape of deirids. Unfortunately, SEM has not so far been used in the majority of spirurine nematodes from fishes. An important specific feature of cystidicolid and rhabdochonid nematodes is the character of their eggs, which, in both groups, may be smooth or covered with a very thin, indistinct gelatinous layer, or the eggs possess polar filaments or caps or equatorial swellings (globules) often designated as floats (Moravec 1972a). It is necessary to note, however, that the eggs should be dissected out from the nematode body to study the presence or 

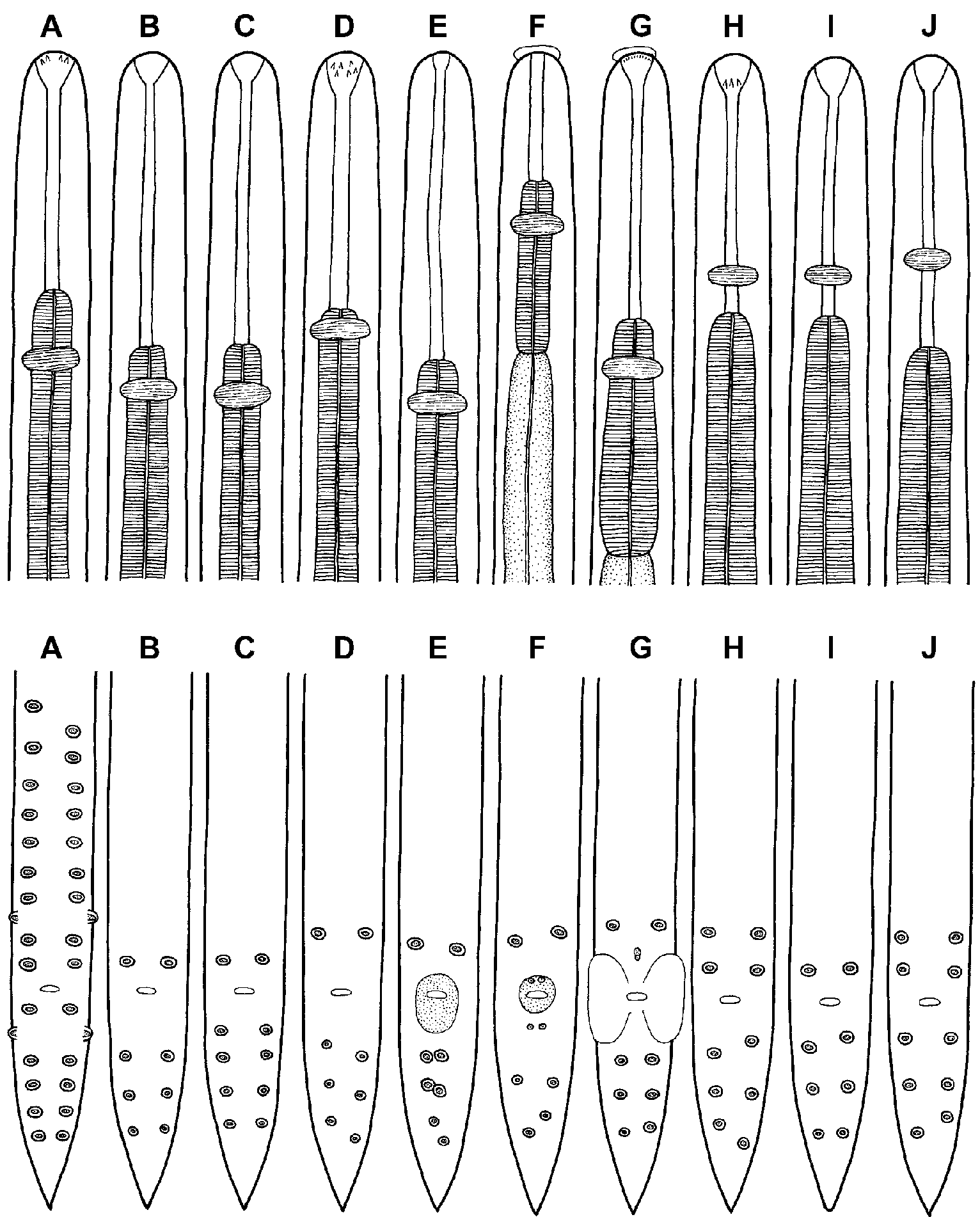

Fig. 5. Variations in position of nerve ring and in numbers and distribution of genital papillae in rhabdochonid nematodes from fishes (schematized). A - Rhabdochona; B - Johnstonmawsonia; C - Vasorhabdochona; D - Megachona; E - Pancreatonema; F - Hepatinema; $\mathbf{G}$ - Heptochona $; \mathbf{H}$ - Beaninema $\mathbf{I}$ - Fellicola; $\mathbf{J}$ - Prosungulonema. 


\section{Cystidicolidae}

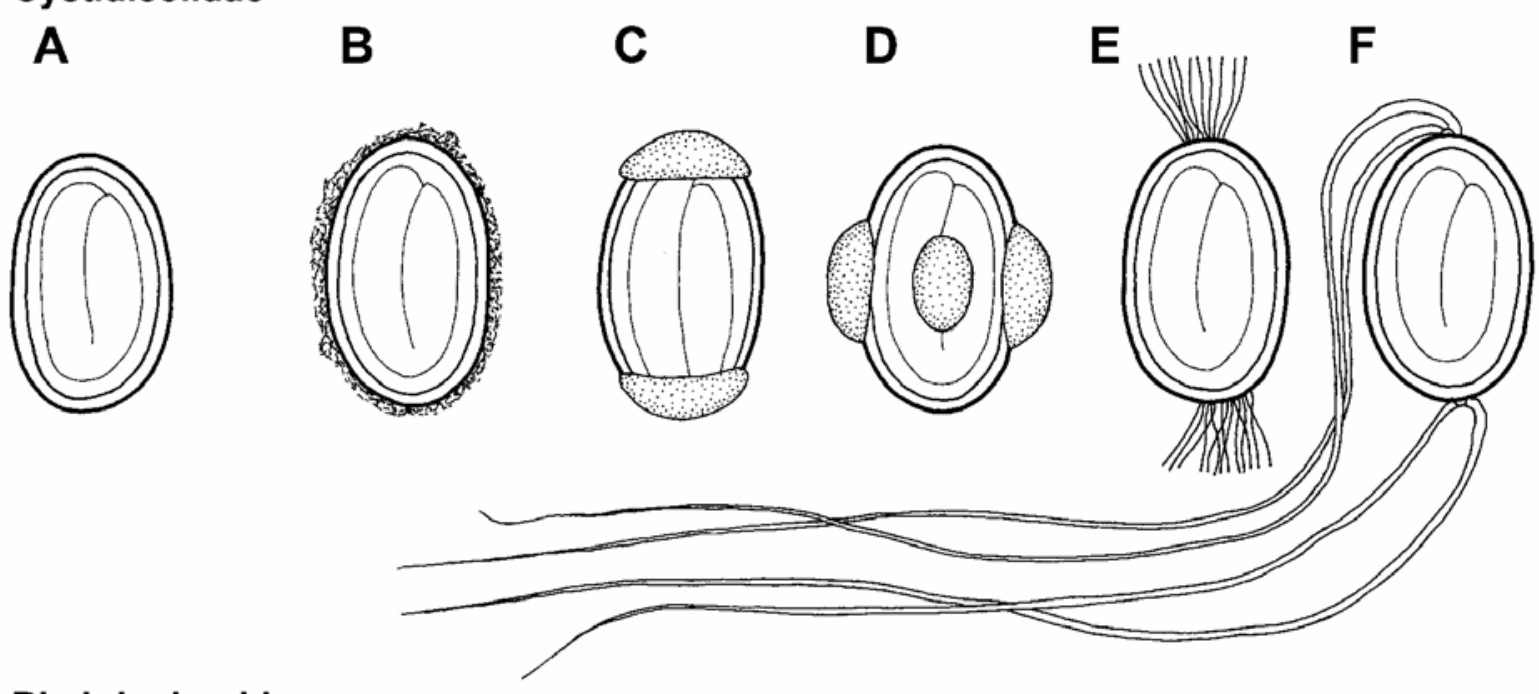

\section{Rhabdochonidae}
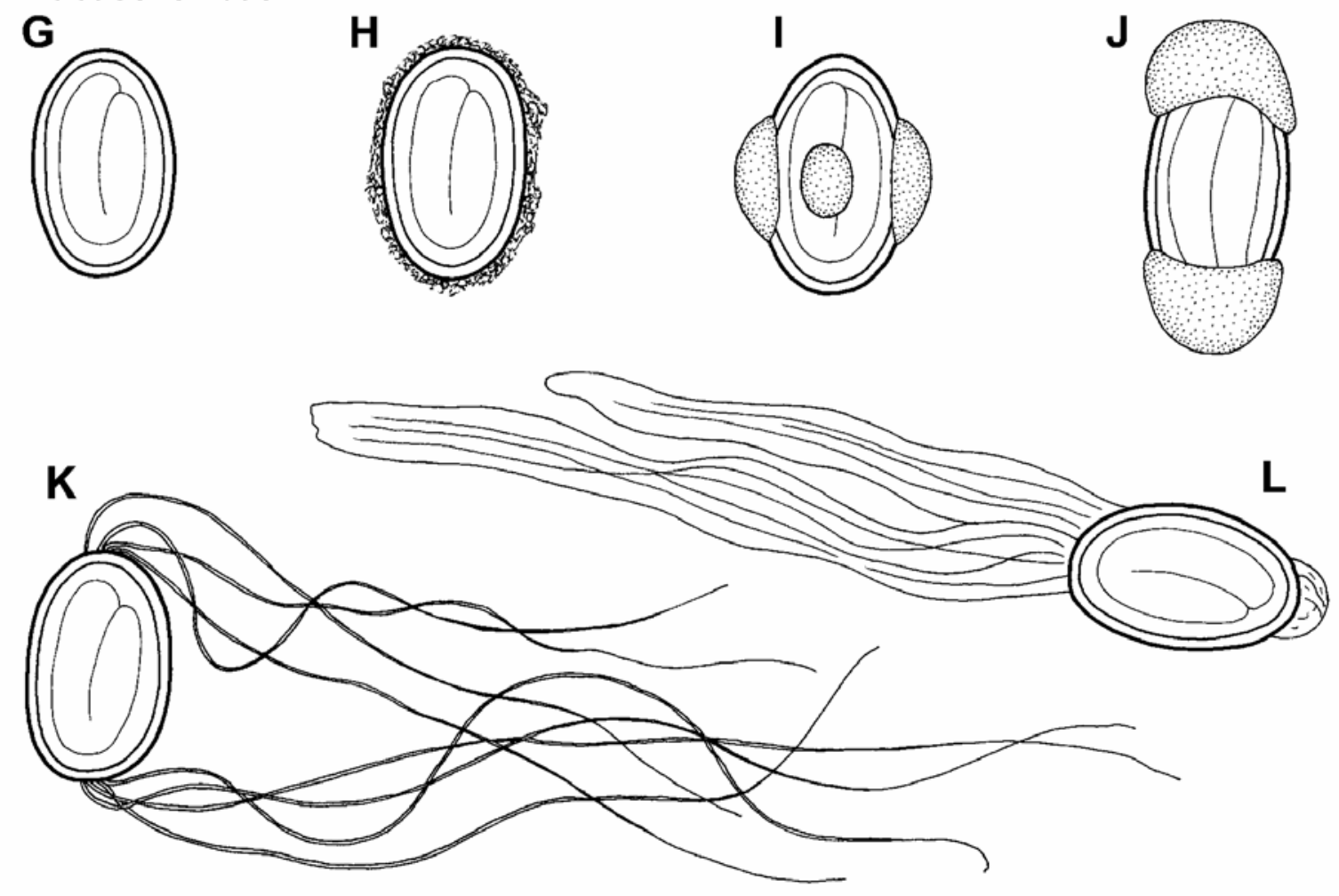

Fig. 6. Variations in superficial formations on eggs in Cystidicolidae and Rhabdochonidae (schematized). A - Spinitectus gordoni; $\mathbf{B}$ - Ascarophis parupenei; $\mathbf{C}$ - Spinitectus inermis; D - Spinitectus agonostomi $; \mathbf{E}$ - Comephoronema oschmarini; $\mathbf{F}$ Metabronema magnum; G - Heptochona maldivensis; $\mathbf{H}$ - Rhabdochona phoxini; I - Rhabdochona barusi; J - Rhabdochona kisutchi; K-Rhabdochona ergensi; $\mathbf{L}$ - Rhabdochona gnedini. 
absence of egg filaments and only fully developed eggs (already containing the larva) should be examined; in younger eggs the filaments are less developed or completely absent.

Although molecular studies provide new possibilities for the solution of many problems of the taxonomy and phylogeny of these nematodes, to date they have been applied quite exceptionally in fish spirurines. In fact, only a few species of fish spirurines of the genera $\mathrm{As}$ carophis, Neoascarophis and Rhabdochona have been characterized by molecular data (Wijová et al. 2006, Nadler et al. 2007).

As Moravec (2004a, 2006) showed for dracunculoids, also the taxonomy and classification of fish spirurines require a fundamental re-evaluation based on detailed studies of individual species, including the use of new methods such as SEM and molecular studies. The new delimitation of genera will have to be based on a combination of morphological features, mainly the structure of the oesophagus, morphology of the cephalic and caudal ends, the arrangement and numbers of genital papillae, and the cuticular ornamentations on the body; the site of infection in the host and host types should also be considered. The delimitation of genera should be strictly based on the principle of type species.

Such a global taxonomic revision will undoubtedly require a broad international collaboration and a multidisciplinary approach to the recognition of this nematode group. The solution of the present unsatisfactory situation in the taxonomy of fish spirurines is urgent, because it can be expected that many new species and new morphological types of these parasites will be discovered from hitherto little-studied geographical regions and from marine fishes.

\section{LIFE CYCLES}

Generally, data on the life cycles of fish spirurines are scarce. Linstow (1872) was probably the first to find fish spirurine larvae, designated as Filaria ephemeridarum (= Sterliadochona ephemeridarum), from the naturally infected intermediate hosts, the mayfly nymphs Ephemera vulgata L. and Oligoneuriella rhenana (Imhoff), in Germany. However, the first attempts to elucidate the development and transmission of some species of fish spirurines experimentally were realized only during the last century.

Within the Gnathostomatidae, no life cycles of species parasitizing fishes as adults have been satisfactorily elucidated. Larvae of Echinocephalus pseudouncinatus Millemann, 1951 were recorded from the foot of the marine mollusc (abalone) Haliotis corrugata Wood and from the gonads of the sea urchin Centrostephanus coronatus Verrill in California (Millemann 1951, Pearse and Timm 1971), whereas those of Echinocephalus sinensis Ko, 1975 and E. overstreeti Deardorff et Ko, 1983 in the oyster Crassostrea gigas (Thunberg) in Hong Kong, China and in the scallops Pecten albus Tate and Chlamys bifrons (Lamarck) in Australia, respectively (Ko 1975, Beveridge 1987); these animals were usually considered as intermediate hosts. However, according to Anderson (2000), it is possible that the intermediate hosts of Echinocephalus spp. are arthropods, probably marine crustaceans such as copepods (as in related species of Gnathostoma Owen, 1836 or Spiroxys Schneider, 1866), and that molluscs, echinoderms and other marine organisms serve as paratenic or second intermediate hosts in which growth occurs.

Nematode larvae 12-22 mm long, found coiled on the top of the brain of the deep-sea fish Cyclothone atraria Gilbert (Gonostomatidae, Stomiiformes) off Japan, were identified by Machida et al. (1982) as Metaleptus rabuka, a gastrointestinal parasite of the deep-sea frilled shark (see above). The authors speculated that the intermediate hosts are copepods and Cyclothone, being the source of infection for sharks, serve as second intermediate or paratenic hosts. Nothing is known about the development and transmission of Ancyracanthus spp., although it can be assumed that some freshwater crustaceans, possibly copepods, serve as their obligate intermediate hosts.

Almost nothing is known about the development and transmission of species of the Proleptinae (Physalopteridae). Only Lloyd (1928) reported on the finding of larvae of Proleptus scillicola $(=P$. obtusus Dujardin, 1845), a parasite of sharks and rays, in naturally infected shore-crabs Carcinus maenas (L.) and Eupagurus bernhardus (L.) in Wales, UK; he also mentioned that conspecific larvae had previously been recorded from $C$. maenas, E. bernhardus, Pachygrapsus marmoratus (Fabricius) and Hyas araneus (L.) in France by Vaullegeard (Vaullegeard A. 1896: Bull. Soc. Linn. Normandie, 4 ser., 10: 50-53). Poinar and Kannangara (1972) described larvae of Proleptus sp., 22-35 mm long, from the hepatopancreas of two species of water crabs, Paratelphusa rugosa (Kingsley) and P. ceylonensis Fernando, in Ceylon (Sri Lanka). Crites and Overstreet (1991) identified the larva found in the white shrimp, Penaeus setiferus (L.), from Mississippi Sound, USA to probably belong to Heliconema brooksi Crites et Overstreet, 1991, a parasite of the shrimp eel Ophichthus gomesii (Castelnau).

Within the Cystidicolidae, the life cycle has been experimentally studied in only 9 (of about 140) species (2 in Europe, 7 in North America) belonging to 5 (of 23) genera: Ascarophis sp. (arctica?) (Valter and Valovaya 1990), Capillospirura pseudoargumentosa (Appy et Dadswell, 1978) (see Appy and Dadswell 1983), Cystidicola farionis Fischer, 1798 (see Smith and Lankester 1979, Black and Lankester 1980), Cystidicola stigmatura (Leidy, 1886) (see Smith and Lankester 1979, Black and Lankester 1980), Spinitectus carolini Holl, 1928 (see Jilek and Crites 1982b), Spinitectus gracilis Ward et Magath, 1917 (see Gustafson 1939, Jilek and Crites 1982c), Spinitectus inermis (Zeder, 1800) (see 
Saraiva et al. 2002a), Spinitectus micracanthus Christian, 1972 (see Keppner 1975) and Sterliadochona ephemeridarum (Linstow, 1872) (see Choquette 1955, Moravec 1971a, De and Moravec 1979).

In addition to these experimental studies on the development of cystidicolids, infective larvae of some genera of these parasites were found in naturally infected intermediate hosts. There are many records of Ascarophis larvae from a variety of marine crustaceans, largely decapods but also amphipods, mysids and isopods, from different parts of the world (for survey see Moravec et al. 2003); besides the Ascarophis larvae, also conspecific adult nematodes (A. arctica, $A$. morrhuae, Ascarophis sp.) were frequently found in gammarids (see Moravec et al. 2003). Larvae of Cystidicola farionis, a Holarctic swimbladder parasite of salmonids, were recorded from different benthic amphipods in Europe and the Russian Far East (for survey see Moravec 2004b), whereas those of the closely related genus Salvelinema in amphipods in Japan and Canada (see Moravec and Nagasawa 1999). As the natural intermediate hosts of Comephoronema oschmarini were found two species of gammarids (see Moravec 1994). Larvae of Spinitectus and Neospinitectus were found in freshwater shrimps (Crustacea) in Japan and India, whereas the third-stage larvae of Spinitectus carolini and $S$. gracilis were recorded from nymphs of various aquatic insects belonging to different orders (Ephemeroptera, Plecoptera and Odonata) and even from Collembola (for survey see Saraiva et al. 2002a). Many species of mayflies (Ephemeroptera) were also found as natural intermediate hosts for Sterliadochona ephemeridarum (Linstow, 1872), a widespread parasite of salmonids, in Europe, Asia (Japan) and North America (Canada) (for survey see Moravec 2004).

All these studies have indicated that the intermediate hosts of most cystidicolids studied (Ascarophis, Capillospirura, Comephoronema, Cystidicola, Neospinitectus, Salvelinema) are various crustaceans, only in the freshwater species Sterliadochona ephemeridarum these are exclusively ephemeropterans (Insecta); in freshwater species of Spinitectus, the intermediate hosts are either nymphs of aquatic insects (largely ephemeropterans) or freshwater shrimps (Crustacea). Generally, the nematode larvae attain the third infective stage in the intermediate host, which is already infective for the fish host; however, in some invertebrates (e.g., gammarids), the development of third-stage larvae of Ascarophis does not cease and they can continue to develop up to adulthood (a precocious development). Usually the intermediate hosts harbouring nematode infective larvae (or adults) are the source of infection for the fish definitive host, but some small fishes may act as paratenic hosts, as demonstrated experimentally and is apparent from field observations in $S$. ephemeridarum (De and Moravec 1979, Moravec and Frantová 2003).
An important part of life history studies of fish nematodes are observations on their seasonal cycles in maturation (Moravec 1994). Within cystidicolids, this has so far been studied mainly in the freshwater species Sterliadochona ephemeridarum in its salmonid hosts in Europe and North America (e.g., Moravec 1971, Hare and Burt 1975, Alvarez-Pellitero 1976, Moravec and De 1982, Aho and Kennedy 1984, Moravec and Frantová 2003), where, depending on local ecological conditions, the parasite's oviposition was throughout the year or there were distinct one or two parasite's generations a year. The only other cystidicolid species in which the seasonal cycles of occurrence and maturation were studied in detail is Spinitectus inermis, a parasite of European eels; this parasite produced eggs all the year round in the Sousa River in Portugal (Saraiva et al. 2002b).

Of the 10 genera of Rhabdochonidae parasitizing fishes, complete or incomplete life cycles have only been experimentally studied in a few representatives of Rhabdochona. Although species of this genus belong to the most frequent and most widely distributed parasites of freshwater fishes, very little is so far known about their development and transmission.

Weller's (1938) data on the experimental infection of crustaceans with the eggs of Rhabdochona ovifilamenta Weller, 1938 and those of Janiszewska (1960) on the finding of the larvae of Rhabdochonoides barbi (= Rhabdochona hellichi Srámek, 1901) in freshwater oligochaetes are evidently faulty (see Moravec and Arai 1971, Moravec 1972a). Gustafson $(1939,1942)$ was the first to successfully infect experimentally several species of mayfly nymphs in North America with the eggs of Rhabdochona spp.; in a short remark he only stated that the larval stages of these nematodes were similar to those of Spinitectus gracilis and that the development in the intermediate host need not cease by reaching the infective stage but could continue. In his later taxonomic paper (Gustafson 1949) he mentioned various mayflies as intermediate hosts of the North American species Rhabdochona cascadilla Wigdor, 1918, R. decaturensis Gustafson, 1949 and $R$. cotti Gustafson, 1949; for the last species also stone-fly nymphs.

Later, the life cycle has been experimentally studied in the European species Rhabdochona denudata (Dujardin, 1845), R. ergensi Moravec, 1968 and R. phoxini Moravec, 1968 and in the North American species $R$. canadensis Moravec et Arai, 1971 and R. kidderi texensis Moravec et Huffman, 1988 (see Moravec 1972c, 1976, 2007b, Barger and Janovy 1994, Moravec and Huffman 2001).

Infective larvae of the following eight species of Rhabdochona have so far been recorded from naturally infected intermediate hosts (aquatic insects): $R$. denudata and $R$. phoxini in ephemeropterans (Caenis, Ecdyonurus, Ephemera, Ephemerella, Heptagenia) and 
R. hellichi and R. ?gnedini Skryabin, 1948 in trichopterans (Hydropsyche) in Europe (Shtein 1959, Vojtková 1971, Moravec 1977, 1989, 1995, 2004, Moravec et al. 1997, Saraiva et al. 2002c), R. coronacauda Belous, 1965, R. denudata honshuensis Moravec et Nagasawa, 1989 and R. oncorhynchi (Fujita, 1921) in ephemeropterans (Ephemera) in Japan (Shimazu 1996, Hirasawa and Urabe 2003, Hirasawa and Yuma 2003), and $R$. cascadilla (syn. $R$. rotundicaudatum) and $R$. kidderi texensis in ephemeropterans (Ephemera, Tricorythodes) in North America (Byrne 1992, Moravec and Huffman 2001).

Observations on the seasonal cycles of the occurrence and maturation of Rhabdochona spp. in their fish definitive hosts have so far been carried out in $R$. anguillae Spaul, 1927, R. denudata, $R$. gnedini, $R$. hellichi and $R$. phoxini in Europe (Czech Republic, Spain, Portugal) (Moravec 1977, 1989, Pereira-Bueno 1978, Moravec and Scholz 1995, Saraiva et al. 2002c, d), R. zacconis Yamaguti, 1935 in Asia (Japan) (Moravec et al. 1998 ), and $R$. canadensis, $R$. cascadilla (as $R$. rotundicaudatum) and R. kidderi Pearse, 1936 in North America (Canada, Mexico) (Byrne 1992, Caspeta-Mandujano et al. 2000, Moravec et al. 2002b, Caspeta-Mandujano and Mejía-Mojica 2004). These studies show that, depending on local ecological conditions, these parasites can produce eggs throughout the year or only during a certain period, mostly in the spring and summer in the temperate zone.

The life cycles of rhabdochonid species belonging to other nine genera, that are parasites of marine fishes, remain unknown. Only Poinar and Kannangara (1972) had described Rhabdochona praecox Poinar et Kannangara, 1972 from mature specimens found in the hepatopancreas of the crab Paratelphusa rugosa (Kingsley) in Ceylon (Sri Lanka), which was subsequently transferred by Moravec (1975) to the genus Heptochona. Apparently, crabs serve as the intermediate hosts for this nematode, the development of which may be precocious in these hosts, like that of some Rhabdochona and $\mathrm{As}$ carophis species in mayflies and some aquatic crustaceans, respectively (see above).

However, even within the spirurine genera in which life cycle have already been studied, the development of most species remains unknown. Of about 300 presently known species of fish spirurines, the life cycle (or at least its portion) has been reported for 16 , or $5 \%$. Moreover, the available data in this respect concern mostly the species parasitic in freshwater fishes, whereas almost nothing is known about the biology of the numerous species from marine fishes. The majority of life cycles of fish spirurines were studied in Europe and North America, less often in East Asia, but, to date, there is no information on the development of spirurines parasitizing fishes in South America, Africa, South Asia and Australia.
However, also in the species where the life cycle has already been studied, the existing data are often limited to the recognition of intermediate hosts either in experimental or in natural conditions. There is usually a lack of detailed data for example on the time course of the development of larvae in the intermediate and definitive hosts, their morphogenesis, on the range of natural intermediate and paratenic hosts in different geographical regions and ecological conditions, factors determining the transmission of these parasites in the environment, seasonal occurrence and maturation in their fish hosts, etc. Such data are also important for the prevention and control of spirurine infections in fish and may be significant from the viewpoint of a possible introduction of these sometimes pathogenic parasites into new geographical regions or even continents.

\section{PROSPECTS}

Although spirurine nematodes represent an important group of fish parasites, their knowledge remains generally poor, but opportunities for more detailed studies have greatly improved with the use of some new methods in helminthology, in particular SEM and DNA studies. The present classification system of these nematodes is unsatisfactory and, in the future, it will be necessary to create a new system of spirurine nematodes with a new delimitation of genera, respecting phylogenetic relationships. A prerequisite for this is a taxonomic revision of the entire group based on detailed studies of individual species, including mainly their morphology, biology and genetics. More attention should be paid to the methods of collection and correct fixation of these nematodes; besides the specimens intended for morphological studies, a few conspecific specimens should always be collected for DNA examination. The species descriptions should be detailed as much as possible, with a special attention to the type species of individual genera. The specimens studied, especially those representing the type material, should be deposited in internationally recognized helminthological collections, where they will be accessible to subsequent researchers.

Molecular methods may be very helpful particularly in distinguishing similar species, in determining nematode larvae from the natural intermediate or paratenic hosts and for phylogenetic studies. More attention should be paid to fish spirurines parasitizing freshwater fishes in the hitherto little explored Neotropical, Ethiopian, Oriental and Australian Regions and those from marine fishes within a broad international collaboration of specialists in different countries.

Very important are also studies on various aspects of the biology, ecology and host-parasite relationships of these parasites. It will be necessary to recognise the lifecycle patterns of the numerous species of Rhabdochona, Ascarophis and of many other genera, particularly those 
where no data exist to date. These investigations should include broad laboratory and field studies, because the data on the biology of these parasites, as those in other nematode groups, may have practical implications.
Acknowledgements. The author thanks the unknown referee for improving the English. This study was supported by grant no. 524/06/0170 from the Grant Agency of the Czech Republic and by the research projects of the Institute of Parasitology, BC ASCR (Z60220518 and LC522).

\section{REFERENCES}

AHO J.M., KENNEDY C.R. 1984: Seasonal population dynamics of the nematode Cystidicoloides tenuissima (Zeder) from the River Swincombe, England. J. Fish Biol. 25: 473-489.

ALVAREZ-PELlitero M.P. 1976: Variaciones estacionales de las infestaciones por Cystidicoloides tenuissima en truchas (Salmo trutta m. fario) de los ríos de la provincia de León. An. Fac. Vet. León 22: 155-180.

ANDERSON R.C. 2000: Nematode Parasites of Vertebrates. Their Development and Transmission. 2nd edition. CABI Publishing, Oxon and New York, 650 pp.

APPY R.G., DADSwELl M.J. 1983: Transmission and development of Capillospirura pseudoargumentosa (Appy and Dadswell, 1978) (Nematoda: Cystidicolidae). Can. J. Zool. 61: 848-859.

BARGER M.A., JANOVY J., Jr. 1994: Host specificity of Rhabdochona canadensis (Nematoda: Rhabdochonidae) in Nebraska. J. Parasitol. 80: 1032-1035.

Bauer O.N., Musselius V.A., Nikolaeva V.M., Strelkov YU.A. 1977: [Ichthyopathology.] Izd. Pishchevaya Promyshlennost, Moscow, 431 pp. (In Russian.)

BEVERIDGE I. 1985: A redescription of Echinocephalus uncinatus Molin, 1858 (Nematoda, Gnathostomatoidea) from European rays, Dasyatis pastinaca (Linnaeus, 1758). Bull. Mus. Natl. Hist. Nat., Paris, sér. 4, sect. A, 7: 781-790.

BEVERIDGE I. 1987: Echinocephalus overstreeti Deardorff \& Ko, 1983 (Nematoda: Gnathostomatoidea) from elasmobranchs and molluscs in South Australia. Trans. R. Soc. S. Aust. 111: 79-92.

BLACK G.A., LANKESTER M.W. 1980: Migration and development of swim-bladder nematodes, Cystidicola spp. (Habronematoidea), in the definitive hosts. Can. J. Zool. 58: $1997-$ 2005.

BYRNE P.J. 1992: On the biology of Rhabdochona rotundicaudatum and $R$. cascadilla (Nematoda: Thelazioidea) in stream fishes from southern Ontario, Canada. Can. J. Zool. 70: 485493.

CASPETA-Mandujano J.M., MeJíA-MojiCA H. 2004: Seasonal dynamics of the occurrence and maturation of Rhabdochona canadensis in its definitive host, Notropis boucardi, of the Chalma River, State of Morelos, Mexico. Helminthologia 41: 121-123.

Caspeta-Mandujano J.M., Moravec F. 2000: Two new intestinal nematodes of Profundulus labialis (Pisces, Cyprinodontidae) from fresh waters in Mexico. Acta Parasitol. 45: 332 339.

CASPETA-ManduJANO J.M., MORAVEC F., DElgado-Yoshino M.A., SALGADO-MALDONADO G. 2000: Seasonal variations in the occurrence and maturation of the nematode Rhabdochona kidderi in Cichlasoma nigrofasciatum of the Amacuzac River, Mexico. Helminthologia 37: 29-33.

ChABAuD A.G. 1974: Class Nematoda. Keys to subclasses, orders and superfamilies. In: R.C. Anderson, A.G. Chabaud and S. Willmott (Eds.), CIH Keys to the Nematode Parasites of Vertebrates. No. 1. Commonwealth Agricultural Bureaux, Farnham Royal, Bucks (UK), pp. 6-17.

ChABAUD A.G. 1975a: Keys to genera of the order Spirurida. Part 1. Camallanoidea, Dracunculoidea, Gnathostomatoidea, Physalopteroidea, Rictularioidea and Thelazioidea. In: R.C.
Anderson, A.G. Chabaud and S. Willmott (Eds.), CIH Keys to the Nematode Parasites of Vertebrates. No. 3. Commonwealth Agricultural Bureaux, Farnham Royal, Bucks (UK), pp. 1-27.

CHABAUD A.G. 1975b: Keys to genera of the order Spirurida. Part 2. Spiruroidea, Habronematoidea and Acuarioidea. In: R.C. Anderson, A.G. Chabaud and S. Willmott (Eds.), CIH Keys to the Nematode Parasites of Vertebrates. No. 3. Commonwealth Agricultural Bureaux, Farnham Royal, Bucks (UK), pp. 2858.

ChABAUD A.G., BAIN O. 1994: The evolutionary expansion of the Spirurida. Int. J. Parasitol. 24: 1179-1201.

CHITwOOD B.G., WEHR E.E. 1934: The value of cephalic structures as characters in nematode classification, with special reference to the superfamily Spiruroidea. Z. Parasitenkd. 7: 273-335.

CHOQUETTE L.P.E. 1955: The life history of the nematode Metabronema salvelini (Fujita, 1920) parasitic in the speckled trout, Salvelinus fontinalis (Mitchill) in Quebec. Can. J. Zool. 33: $1-4$.

CRITES J.L., OvERSTREET R.M. 1991: Heliconema brooksi n. sp. (Nematoda: Physalopteridae) from the ophichthid eel Ophichthus gomesi in the Gulf of Mexico. J. Parasitol. 77: 42-50.

DE N.C., MORAVEC F. 1979: Some new data on the morphology and development of the nematode Cystidicoloides tenuissima (Zeder, 1800). Folia Parasitol. 26: 231-237.

DEARDORFF T.L., KO R.C. 1983: Echinocephalus overstreeti sp. n. (Nematoda: Gnathostomatidae) in the stingray, Taeniura melanopilos [sic] Bleeker, from the Marquesas Islands, with comments on E. sinensis Ko, 1975. Proc. Helminthol. Soc. Wash. 50: 285-293.

DE LEY P., BLAXTER M. 2002: Systematic position and phylogeny. In: D.L. Lee (Ed.), The Biology of Nematodes. Taylor \& Francis, London and New York, pp. 1-30.

DE LEY P., BlaXTeR M. 2004: A new system for Nematoda: combining morphological characters with molecular trees, and translating clades into ranks and taxa. Nematol. Monogr. Perspect. 2: 633-653.

DIESING C.M. 1839: Neue Gattungen von Binnenwürmern nebst einem Nachtrage zur Monographie der Amphistomen. Ann. Wien. Mus. Naturgesch. 2: 219-242.

FERRER E., AZNAR F.J., BALBUENA J.A., KostadinOVA A., RAGA J.A., MORAVEC F. 2005: A new cystidicolid nematode from Mullus surmuletus (Perciformes: Mullidae) from the western Mediterranean. J. Parasitol. 91: 335-344.

FISCHER VON WALDHEIM G. 1798: Sur un nouveau genre de vers intestins, Cystidicola farionis, suivi de quelques remarques sur les milieaux dans lesquels les vers intestins vivent. J. Phys. Chim. Hist. Nat. Paris 4: 304-309.

FRANTOVÁ D., MORAVEC F. 2003: Ultrastructure of the body wall of Cystidicoloides ephemeridarum (Nematoda, Cystidicolidae) in relation to the histopathology of this nematode in salmonids. Parasitol. Res. 91: 100-108.

FRANTOVÁ D., MORAVEC F. 2004a: Ultrastructure of the body wall of infective larvae of Cystidicoloides ephemeridarum (Nematoda, Cystidicolidae) from mayflies. Parasitol. Res. 94: 106-111.

FrantovÁ D., MoraVeC F. 2004b: Comparative studies on intestine ultrastructure of third-stage larvae and adults of Cys- 
tidicoloides ephemeridarum (Nematoda, Cystidicolidae). Parasitol. Res. 94: 377-383.

FusCO A.C., PALMIERI J.R. 1980: Heliconema serpens sp. $\mathrm{n}$. (Nematoda: Physalopteridae) and Camallanides malayensis sp. n. (Nematoda: Camallanidae) from Cerberus rhynchops (Schneider) (Reptilia: Colubridae) in Malaysia. Proc. Helminthol. Soc. Wash. 47: 72-79.

GOMES D.C., KOHN A. 1970: Sôbre a subfamília "Ancyracanthinae" Yourke et Maplestone, 1926 (Nematoda, Spiruroidea). Atas Soc. Biol. Rio de J. 13: 83-88 + 11 Figs.

GUSTAFSON P.V. 1939: Life cycle studies on Spinitectus gracilis and Rhabdochona sp. (Nematoda: Thelaziidae). J. Parasitol. 25 (Suppl.): 12-13.

GUSTAFSON P.V. 1942: A peculiar larval development of Rhabdochona spp. (Nematoda: Thelaziidae). J. Parasitol. 28 (Suppl.): 30.

GUSTAFSON P.V. 1949: Description of some species of Rhabdochona (Nematoda: Thelaziidae). J. Parasitol. 35: 534-540.

HARE G.M., BURT M.D.B. 1975: Abundance and population dynamics of parasites infecting Atlantic salmon (Salmo salar) in Trout Brook, New Brunswick, Canada. J. Fish. Res. Board Can. 32: 2069-2074.

HIRASAWA R., URABE M. 2003: Ephemera strigata (Insecta: Ephemeroptera: Ephemeridae) is the intermediate host of the nematodes Rhabdochona denudata honshuensis and Rhabdochona coronacauda in Japan. J. Parasitol. 89: 617-620.

HIRASAWA R., YUMA M. 2003: Ephemera strigata imagoes are the likely source of a parasitic nematode infection of fish. Folia Parasitol. 50: 313-314.

Hoberg E.P., BroOKS D.R., MolinA-UreÑA H., ERBE E. 1998: Echinocephalus janzeni $\mathrm{n}$. sp. (Nematoda: Gnathostomatidae) in Himantura pacifica (Chondrichthyes: Myliobatiformes) from the Pacific coast of Costa Rica and Mexico, with historical biogeographic analysis of the genus. J. Parasitol. 84: 571581.

IVASHKIN V.M., KHROMOVA L.A. 1976: [Cucullanata and Gnathostomatata of Animals and Man and the Diseases Caused by Them.] Osnovy Nematodologii 27. Nauka, Moscow, 436 pp. (In Russian.)

JANISZEWSKA J. 1960: Studies on larval nematodes in Tubificidae (a hypothesis on the life-cycle of Rhabdochonidae). Acta Parasitol. Pol. 8: 419-425.

JILEK R., CRITES J.L. 1982a: Intestinal histopathology of the common bluegill, Lepomis macrochirus Rafinesque, infected with Spinitectus carolini Holl, 1928 (Spirurida: Nematoda). J. Fish Dis. 5: 75-77.

JILEK R., CRITES J.L. 1982b: The life cycle and development of Spinitectus carolini Holl, 1928 (Nematoda: Spirurida). Am. Midl. Nat. 107: 100-106.

JiLEK R., CRITES J.L. 1982c: The life cycle and development of Spinitectus gracilis (Nematoda: Spirurida). Trans. Am. Microsc. Soc. 101: 75-83.

Justine J.-L., CASSONE J., PetTER A. 2002: Moravecnema segonzaci gen. et sp. n. (Nematoda: Cystidicolidae) from $\mathrm{Pa}$ chycara thermophilum (Zoarcidae), a deep-sea hydrothermal vent fish from the Mid-Atlantic Ridge. Folia Parasitol. 49: 299-303.

KEPPNER E.J. 1975: Life cycle of Spinitectus micracanthus Christian, 1972 (Nematoda: Rhabdochonidae) from the bluegill, Lepomis macrochirus Rafinesque, in Missouri with note on Spinitectus gracilis Ward and Magath, 1917. Am. Midl. Nat. 93: 411-423.

KinKelin P., Gerard J.P., TUFFERY G. 1973: Pathologie des poissons d'eau douce. II. Causes infectieuses: les maladies leur traitement. Inform. Techniq. Serv. Vét. No. 43/44, pp. $43-62$.
Klimpel S., Seehagen A., Palm H.-W., Rosenthal H. 2001: Deep-Water Metazoan Fish Parasites of the World. Logos Verlag, Berlin, 315 pp.

Ko R.C. 1975: Echinocephalus sinensis n. sp. (Nematoda: Gnathostomatidae) from the ray (Aetabatus flagellum) in Hong Kong, Southern China. Can. J. Zool. 53: 490-500.

Ko R.C. 1986: A Preliminary Review of the Genus Ascarophis van Beneden, 1871 (Nematoda: Cystidicolidae) of the Gastrointestinal Tract of Fishes. Department of Zoology, University of Hong Kong, Hong Kong, China, 54 pp.

Ko R.C., ANDERSON R.C. 1969: A revision of the genus Cystidicola Fischer, 1798 (Nematoda: Spiruroidea) of the swim bladder of fishes. J. Fish. Res. Board Can. 26: 849-864.

LINSTOW O. 1872: Beobachtungen an Helminthenlarven. Arch. Mikrosk. Anat. 39: 325-343.

LLOYD J.H. 1928: On the life-history of the common nematode of the dogfish (Scyllium canicula). Ann. Mag. Nat. Hist., Ser. 10, 1: 712-714.

MaChidA M., OGAWA K., OKIYAMA M. 1982: A new nematode (Spirurida, Physalopteridae) from frill shark in Japan. Bull. Nat. Sci. Mus., Tokyo, Ser. A (Zool.), 8: 1-5.

MARGOLIS L. 1963: Parasites as indicators of the geographical origin of sockeye salmon, Oncorhynchus nerka (Walbaum), occurring in the North Pacific Ocean and adjacent seas. Int. North Pac. Fish. Comm. Bull. no. 11, pp. 101-156.

MARGOLIS L. 1967: The swimbladder nematodes (Cystidicolinae) of Pacific salmons (genus Oncorhynchus). Can. J. Zool. 45: 1183-1199.

MejÍA-MAdRID H.H., CHOUdHuRY A., PÉREZ-PONCE DE LEÓN G. 2007: Phylogeny and biogeography of Rhabdochona Railliet, 1916 (Nematoda: Rhabdochonidae) species from the Americas. Syst. Parasitol. 67: 1-18.

MEJÍA-MADRID H.H., PÉREZ-PONCE DE LEÓN G. 2007: A new rhabdochonid from the blue striped chub Sectator ocyurus (Osteichthyes: Kyphosidae) in Chamela Bay, Mexico. J. Parasitol. 93: 166-170.

MiLLEMANN R.E. 1951: Echinocephalus pseudouncinatus n. sp., a nematode parasite of the abalone. J. Parasitol. 37: 435-439.

MORAVEC F. 1971a: Studies on the development of the nematode Cystidicoloides tenuissima (Zeder, 1800). Acta Soc. Zool. Bohemoslov. 35: 43-55.

MORAVEC F. 1971b: On the life history of the nematode Cystidicoloides tenuissima (Zeder, 1800) in the River Bystřice, Czechoslovakia. Folia Parasitol. 18: 107-112.

MORAVEC F. 1972a: General characterization of the nematode genus Rhabdochona with a revision of the South American species. Acta Soc. Zool. Bohemoslov. 36: 29-46.

MORAVEC F. 1972b: A revision of African species of the nematode genus Rhabdochona Railliet, 1916. Acta Soc. Zool. Bohemoslov. 36: 196-208.

MORAVEC F. 1972c: Studies on the development of the nematode Rhabdochona (Filochona) ergensi Moravec, 1968. Folia Parasitol. 19: 321-333.

MORAVEC F. 1975: Reconstruction of the Nematode Genus Rhabdochona Railliet, 1916 With a Review of the Species Parasitic in Fishes of Europe and Asia. Studie ČSAV No. 8. Academia, Prague, $104 \mathrm{pp}$.

MORAVEC F. 1976: Observations on the development of Rhabdochona phoxini Moravec, 1968 (Nematoda: Rhabdochonidae). Folia Parasitol. 23: 309-320.

MORAVEC F. 1977: Life history of the nematode Rhabdochona phoxini Moravec, 1968 in the Rokytka Brook, Czechoslovakia. Folia Parasitol. 24: 97-105.

MORAVEC F. 1981: The systematic status of Filaria ephemeridarum Linstow, 1872. Folia Parasitol. 28: 377-379 + Plts. I, II. 
MORAVEC F. 1989: Observations on the occurrence and maturation of the nematode Rhabdochona denudata (Dujardin, 1845) in chub, Leuciscus cephalus (L.) of the Rokytná River, Czechoslovakia. Parassitologia 31: 25-35.

MORAVEC F. 1994: Parasitic Nematodes of Freshwater Fishes of Europe. Academia and Kluwer Academic Publishers, Prague and Dordrecht, Boston, London, $473 \mathrm{pp}$.

MORAVEC F. 1995: Trichopteran larvae (Insecta) as the intermediate hosts of Rhabdochona hellichi (Nematoda: Rhabdochonidae), a parasite of Barbus barbus (Pisces). Parasitol. Res. 81: 268-270.

MORAVEC F. 1998: Nematodes of Freshwater Fishes of the Neotropical Region. Academia, Prague, 464 pp.

MORAVEC F. 2004a: Some aspects of the taxonomy and biology of dracunculoid nematodes parasitic in fishes: a review. Folia Parasitol. 51: 1-13.

MoRAVEC F. 2004b: Metazoan Parasites of Salmonid Fishes of Europe. Academia, Prague, 510 pp.

MORAVEC F. 2007a: Nematode parasites of fishes: recent advances and problems of their research. Parassitologia 49: $155-160$.

MORAVEC F. 2007b: First experimental observations on the development of Rhabdochona denudata (Nematoda: Rhabdochonidae) in the intermediate host. Folia Parasitol. 54: 236238.

MORAVEC F., ARAI H.P. 1971: The North and Central American species of Rhabdochona Railliet, 1916 (Nematoda: Rhabdochonidae) of fishes, including Rhabdochona canadensis sp. nov. J. Fish. Res. Board Can. 28: 1645-1662.

MORAVEC F., DE N.C. 1982: Some new data on the bionomics of Cystidicoloides tenuissima (Nematoda: Cystidicolidae). Acta Soc. Zool. Bohemoslov. 46: 100-108+ 2 Plts.

MORAVEC F., FRANTOVÁ D. 2003: Observations on the transmission and the seasonality of infection of the nematode Cystidicoloides ephemeridarum in Salmo trutta fario in a small trout stream in North Bohemia, the Czech Republic. Acta Parasitol. 48: $41-46$.

Moravec F., Fredensborg B.L., LAtham A.D.M., Poulin R. 2003: Larval Spirurida (Nematoda) from the crab Macrophthalmus hirtipes in New Zealand. Folia Parasitol. 50: 109-114.

MoRAVEC F., GONZÁLEZ-Solís D. 2007: Structure of the cephalic end of Ascarophis mexicana (Nematoda: Cystidicolidae), as revealed by SEM. Folia Parasitol. 54: 155-156.

MORAVEC F., HANZELOVÁ V., GERDEAUX D. 2007b: New data on the morphology of Comephoronema oschmarini (Nematoda, Cystidicolidae), a little-known gastrointestinal parasite of Lota lota (Teleostei) in Palaearctic Eurasia. Acta Parasitol. 52: 135-141.

MORAVEC F., HUFFMAN D.G. 2001: Observations on the biology of Rhabdochona kidderi texensis, a parasite of North American cichlids. J. Helminthol. 75: 197-203.

MORAVEC F., JUSTINE J.-L. 2006: Three nematode species from elasmobranchs off New Caledonia. Syst. Parasitol. 64: 131145.

MORAVEC F., Justine J.-L. 2007a: A new species of Ascarophis (Nematoda, Cystidicolidae) from the stomach of the marine scorpaeniform fish Hoplichthys citrinus from a seamount off the Chesterfield Islands, New Caledonia. Acta Parasitol. 52: 238-246.

MoRAVEC F., Justine J.-L. 2007b: Redescription of Metabronema magnum (Nematoda: Cystidicolidae), a swimbladder parasite of the carangid fish Gnathanodon speciosus off New Caledonia. Folia Parasitol., in press.

MORAVEC F., KLIMPEL S. 2007a: New data on the morphology of Spinitectus oviflagellis Fourment, 1884 (Nematoda: Cystidi- colidae) from the pyloric caeca of Macrourus berglax (Macrouridae) in the eastern Greenland Sea. Syst. Parasitol. 67: 43-50.

MORAVEC F., KLIMPEL S. 2007b: A new species of Comephoronema (Nematoda: Cystidicolidae) from the stomach of the abyssal halosaur Halosauropsis macrochir (Teleostei) from the Mid-Atlantic Ridge. J. Parasitol. 93: 901-906.

MORAVEC F., KLIMPEL S., KARA E. 2006: Neoascarophis macrouri n. sp. (Nematoda: Cystidicolidae) from the stomach of Macrourus berglax (Macrouridae) in the eastern Greenland Sea. Syst. Parasitol. 63: 231-237.

Moravec F., KoneČnÝ R., BASKA F., Rydlo M., Scholz T., MOLNÁR K., SCHIEMER F. 1997: Endohelminth Fauna of Barbel, Barbus barbus (L.), Under Ecological Conditions of the Danube Basin in Central Europe. Studie AV ČR/3 1997. Academia, Prague, 96 pp.

Moravec F., Mendoza-Franco E., Vivas-Rodríguez C., VARGAS-VÁZQUEZ J., GONZÁLEZ-SOLÍS D. 2002b: Observations on seasonal changes in the occurrence and maturation of five helminth species in the pimelodid catfish, Rhamdia guatemalensis, in the cenote (= sinkhole) Ixin-há, Yucatán, Mexico. Acta Soc. Zool. Bohem. 66: 121-140.

MORAVEC F., MuZZALl P. 2007: Redescription of Rhabdochona cotti (Nematoda, Rhabdochonidae) from Cottus caeruleomentum (Teleostei, Cottidae) in Maryland, USA, with remarks on the taxonomy of North American Rhabdochona spp. Acta Parasitol. 52: 51-57.

MORAVEC F., NAGASAWA K. 1999: Morphology and taxonomy of Salvelinema species (Nematoda: Cystidicolidae), swimbladder parasites of Pacific area salmonids. Folia Parasitol. 46: $123-131$.

MORAVEC F., NAGASAWA K. 2000: Two remarkable nematodes from sharks in Japan. J. Nat. Hist. 34: 1-13.

MORAVEC F., NAGASAWA K., URUSHIBARA Y. 1998: Observations on the seasonal maturation of the nematode Rhabdochona zacconis in Japanese dace, Tribolodon hakonensis, of the Okitsu River, Japan. Acta Soc. Zool. Bohem. 62: 45-60.

MorAVEC F., NiE P., WANG G. 2004: New data on the morphology and systematic status of Spinitectus petrowi and Spinitectus gigi (Nematoda: Cystidicolidae) parasitic in catfishes in central China. Folia Parasitol. 51: 346-358.

MORAVEC F., ROKICKI J. 2002: Some new data on the morphology of Cystidicola farionis (Nematoda, Cystidicolidae), a swimbladder parasite of salmonids, as revealed by SEM. Acta Parasitol. 47: 29-33.

MorAVEC F., SAlGAdO-MALdONAdO G., CABAÑAS-CARRANZA G. 2001: New observations on Vasorhabdochona cablei (Nematoda: Rhabdochonidae) with remarks to the family Rhabdochonidae. Helminthologia 38: 231-235.

MorAVEC F., SANTOS M.D., BRASIL-SATO M.C. 2008: Redescription of Cystidicoloides fischeri based on specimens from piranhas in Brazil, and erection of a new genus (Nematoda: Cystidicolidae). J. Parasitol., in press.

MORAVEC F., SCHOLZ T. 1995: Life history of the nematode Rhabdochona hellichi, a parasite of the barbel in the Jihlava River, Czech Republic. J. Helminthol. 69: 59-64.

MORAVEC F., TARASCHEWSKI H., ANANTAPHRUTI M.T., MAIPANICH W., LAOPRASERT T. 2007a: Heliconema longissimum (Ortlepp, 1923) (Nematoda: Physalopteridae) from Pisodonophis boro (Teleostei: Ophichthidae) in Thailand, with remarks on the taxonomy of the Proleptinae Schulz, 1927. Syst. Parasitol. 66: 73-80.

Moravec F., VAN As J.G., DYKOvÁ I. 2002a: Proleptus obtusus Dujardin, 1845 (Nematoda: Physalopteridae) from the puffadder shyshark Haploblepharus edwardsii (Scyliorhinidae) from off South Africa. Syst. Parasitol. 53: 169-173. 
MuÑoz G., GONZÁLEZ M.T., GeORGE-NASCIMENTO M. 2004 Similascarophis n. gen. n. sp. (Nematoda: Cystidicolidae) parasitizing marine fishes off the Chilean coast. J. Parasitol. 90: 823-834.

NAdler S.A., CARRENo R.A., MeJía-Madrid H., Ullberg J., PAGAN C., Houston R., HugOt J.-P. 2007: Molecular phylogeny of clade III nematodes reveals multiple origins of tissue parasitism. Parasitology 134: 1421-1442.

ODENING K. 1976: Conception and terminology of hosts in parasitology. Adv. Parasitol. 14: 1-93.

PEARSE J.S., TimM R.W. 1971: Juvenile nematodes (Echinocephalus pseudouncinatus) in the gonads of sea urchins (Centrostephanus coronatus) and their effect on host gametogenesis. Biol. Bull. 140: 95-103.

PEREIRA-BUENO J.M. 1978: Seasonal occurrence of Rhabdochona spp. in cyprinid fishes of the rivers of León (NW. Spain). Proc. IVth Int. Congr. Parasitol., Warsaw, 19-26 Aug. 1978, Sec. H, pp. 45-46.

PETTER A.-J. 1971: Redescription d'Hedruris androphora Nitzsch, 1821 (Nematoda, Hedruridae) et étude de son developpement chez l'hôte intermediaire. Ann. Parasitol. Hum. Comp. 46: 479-495.

POINAR G.O., JR., KANNANGARA D.W.W. 1972: Rhabdochona praecox sp. n. and Proleptus sp. (Spiruroidea: Nematoda) from fresh water crabs in Ceylon. Ann. Parasitol. Hum. Comp. 47: 121-129.

RASHEED S. 1965: A preliminary review of the genus Rhabdochona Railliet, 1916 with description of a new and related genus. Acta Parasitol. Pol. 13: 407-424.

RASHEED S. 1966: Observations on the spiruroid nematodes of fish with a revision of the genus Metabronema Yorke and Maplestone, 1926. Z. Zool. Syst. Evolutionsforsch. 3: 359387.

SARAIVA A.M., Felisberto P., CRUZ C. 2002c: Occurrence and maturation of Rhabdochona gnedini (Nematoda: Rhabdochonidae) in the barbels of the Sousa River, Portugal. Parasite 9: $81-84$

Saraiva A.M., Moravec F., Pereira A., Cruz C. 2002a: Development of Spinitectus inermis (Nematoda: Cystidicolidae), a parasite of eel, Anguilla anguilla, in Europe. Folia Parasitol. 49: 118-126.

Saraiva A.M., Pereira A., CruZ C. 2002b: Observations on the occurrence and maturation of Spinitectus inermis (Nematoda: Cystidicolidae) in the Sousa River, Portugal. Folia Parasitol. 49: 167-168.

SARAiva A.M., Pereira A., CRUZ C. 2002d: Observations on the occurrence and maturation of Rhabdochona anguillae (Nematoda: Rhabdochonidae) in the Sousa River, Portugal. Helminthologia 39: 41-43.
SCHÄPERCLAUS W. 1954: Fischkrankheiten. Akademie-Verlag, Berlin, 708 pp.

SHIMAZU T. 1996: Mayfly larvae, Ephemera japonica, as natural intermediate hosts of salmonid nematodes, Sterliadochona ephemeridarum and Rhabdochona oncorhynchi, in Japan. Jpn. J. Parasitol. 45: 167-172.

SHTEIN G.A. 1959: [On the questions of the life history and living conditions of the nematode Rhabdochona denudata (Dujardin, 1845).] Dokl. AN SSSR 127: 1320-1321. (In Russian.)

SKRYABIN K.I., SOBOLEV A.A. 1964: [Spirurata of Animals and Man and the Diseases Caused by Them. Spirurata Part 2, Physalopteroidea.] Osnovy Nematodologii 12. Nauka, Moscow, 334 pp. (In Russian.)

SKRYABIN K.I., SOBOLEV A.A., IVASHKIN V.M. 1967a: [Spirurata of Animals and Man and the Diseases Caused by Them. Spirurata Part 4, Thelazioidea.] Osnovy Nematodologii 16. Nauka, Moscow, 624 pp. (In Russian.)

SKRYABIN K.I., SOBOLEV A.A., IVASHKIN V.M. 1967b: [Spirurata of Animals and Man and the Diseases Caused by Them. Spirurata Part 5, Supplement.] Osnovy Nematodologii 19. Nauka, Moscow, 239 pp. (In Russian.)

SKRYABINA E.S. 1974: [Helminths of Acipenserid Fishes.] Nauka, Moscow, 168 pp. (In Russian.)

SMITH J.D., LANKESTER M.W. 1979: Development of swim bladder nematodes (Cystidicola spp.) in their intermediate hosts. Can. J. Zool. 57: 1736-1744.

SpeCian R.D., UbelaKeR J.E., DAILEY M.D. 1975: Neoleptus gen. n. and a revision of the genus Proleptus Dujardin, 1845. Proc. Helminthol. Soc. Wash. 42: 14-21.

TROFIMENKO V.Ya. 1974: [New data on nematodes of the genera Cottocomephoronema and Comephoronema, parasites of burbot]. Tr. GELAN 24: 199-207. (In Russian.)

VALTER E.D., VALOVAYA M.A. 1990: [Experimental confirmation of the participation of crustaceans in the life cycle of the nematode Ascarophis sp. (arctica?).] In: "Morfologiya i Ekologiya Parazitov Morskikh Zhivotnykh", Kolskiy Nauchn. Tsentr AN SSSR, Apatity, pp. 33-48. (In Russian.)

VOJTKOVÁ L. 1971: Beitrag zur Kenntnis der Helmintofauna der Wasserwirbellosen. III. Cestoda, Nematoda, Acanthocephala. Acta Soc. Zool. Bohemoslov. 35: 146-155.

WELLER T.H. 1938: Description of Rhabdochona ovifilamenta n. sp. (Nematoda: Thelaziidae) with a note on the life history. J. Parasitol. 24: 403-408.

WiJOVÁ M., MORAVEC F., HORÁK A., LUKEŠ J. 2006: Evolutionary relationships of Spirurina (Nematoda: Chromadorea: Rhabditida) with special emphasis on dracunculoid nematodes inferred from SSU rRNA gene sequences. Int. J. Parasitol. 36: 1067-1075.

Accepted 18 September 2007 